University of New Hampshire

University of New Hampshire Scholars' Repository

Faculty Publications

$1-1-2003$

\title{
Factors affecting ammonium uptake in streams - an inter-biome perspective
}

Jackson R. Webster

Patrick J. Mulholland

Oak Ridge National Laboratory

Jennifer L. Tanks

H. Maurice Valett

Walter K. Dodds

Kansas State University

See next page for additional authors

Follow this and additional works at: https://scholars.unh.edu/faculty_pubs

\section{Comments}

This article was written and prepared by U.S. Government employees on official time, and is therefore in the public domain.

\section{Recommended Citation}

Webster, J.R., P.J. Mulholland, J.L. Tank, H.M. Valett, W.K. Dodds, B.J. Peterson, W.B. Bowden, C.N. Dahm, S. Findlay, S.V. Gregory, N.B. Grimm, S.K. Hamilton, S.L. Johnson, E. Marti, W.H. McDowell, J.L. Meyer, D.D. Morrall, S.A. Thomas, and W.M. Wollheim. 2003. Factors affecting ammonium uptake in streams - an inter-biome perspective. Freshwater Biology 48:1329-1352.

This Article is brought to you for free and open access by University of New Hampshire Scholars' Repository. It has been accepted for inclusion in Faculty Publications by an authorized administrator of University of New Hampshire Scholars' Repository. For more information, please contact Scholarly.Communication@unh.edu. 


\section{Authors}

Jackson R. Webster, Patrick J. Mulholland, Jennifer L. Tanks, H. Maurice Valett, Walter K. Dodds, Bruce J. Peterson, William B. Bowden, Clifford N. Dahm, Stuart Findlay, Stanley V. Gregory, Nancy B. Grimm, Stephen K. Hamilton, Sherri L. Johnson, Eugenia Marti, William H. McDowell, Judy L. Meyer, Donna D. Morrall, Steven A. Thomas, and Wilfred M. Wollheim 


\title{
Factors affecting ammonium uptake in streams - an inter-biome perspective
}

\author{
JACKSON R. WEBSTER*, PATRICK J. MULHOLLAND ${ }^{\dagger}$, JENNIFER L. TANK ${ }^{\ddagger}$, H. MAURICE \\ VALETT*, WALTER K. DODDS ${ }^{\S}$, BRUCE J. PETERSON", WILLIAM B. BOWDEN**, CLIFFORD N.

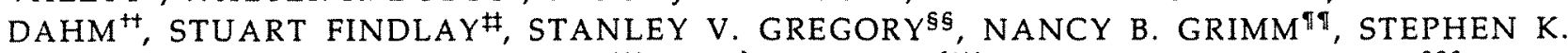 \\ HAMILTON***, SHERRI L. JOHNSON ${ }^{++}$, EUGENIA MARTÍ ${ }^{*}$, WILLIAM H. MCDOWELL $\$ \S \S$, JUDY \\ L. MEYER 1 II, DONNA D. MORRALL***, STEVEN A. THOMAS ${ }^{+++}$AND WILFRED M. \\ WOLLHEIM
}

*Department of Biology, Virginia Polytechnic Institute and State University, Blacksburg, VA, U.S.A.

+Environmental Sciences Division, Oak Ridge National Laboratory, Oak Ridge, TN, U.S.A.

$\ddagger$ Department of Biological Sciences, University of Notre Dame, Notre Dame, IN, U.S.A.

§Division of Biology, Kansas State University, Manhattan, KS, U.S.A.

ๆEcosystems Center, Marine Biological Laboratory, Woods Hole, MA, U.S.A.

** School of Natural Resources, University of Vermont, Burlington, VT, U.S.A.

t+Department of Biology, University of New Mexico, Albuquerque, NM, U.S.A.

\#tInstitute of Ecosystem Studies, Millbrook, NY, U.S.A.

$\S \S$ Department of Fisheries and Wildlife, Oregon State University, Corvallis, OR, U.S.A.

ITDepartment of Biology, Arizona State University, Tempe, AZ, U.S.A.

***Kellogg Biological Station, Michigan State University, E Gull Lake Dr., Hickory Corners, MI, U.S.A.

+t+USDA Forest Service, PNW Research Station, Corvallis, OR, U.S.A.

\#\#Centre d'Estudis Avancats de Blanes (CSIC), Blanes, Girona, Spain

$\S \S \S$ Department of Natural Resources, University of New Hampshire, Durham, NH, U.S.A.

IfqIInstitute of Ecology, University of Georgia, Athens, GA, U.S.A.

****Environmental Science Department, Procter and Gambell Company, Cincinnati, OH, U.S.A.

t+t+Eco-Metrics, Inc., Pendleton, OR, U.S.A.

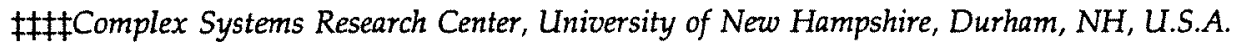

\section{SUMMARY}

1. The Lotic Intersite Nitrogen eXperiment (LINX) was a coordinated study of the relationships between North American biomes and factors governing ammonium uptake in streams. Our objective was to relate inter-biome variability of ammonium uptake to physical, chemical and biological processes.

2. Data were collected from 11 streams ranging from arctic to tropical and from desert to rainforest. Measurements at each site included physical, hydraulic and chemical characteristics, biological parameters, whole-stream metabolism and ammonium uptake. Ammonium uptake was measured by injection of ${ }^{15} \mathrm{~N}$-ammonium and downstream measurements of ${ }^{15} \mathrm{~N}$-ammonium concentration.

3. We found no general, statistically significant relationships that explained the variability in ammonium uptake among sites. However, this approach does not account for the multiple mechanisms of ammonium uptake in streams. When we estimated biological demand for inorganic nitrogen based on our measurements of in-stream metabolism, we found good correspondence between calculated nitrogen demand and measured assimilative nitrogen uptake.

Correspondence: J. R. Webster, Department of Biology, Virginia Polytechnic Institute and State University, Blacksburg, VA, U.S.A. E-mail: jwebster@vt.edu 
4. Nitrogen uptake varied little among sites, reflecting metabolic compensation in streams in a variety of distinctly different biomes (autotrophic production is high where allochthonous inputs are relatively low and vice versa).

5. Both autotrophic and heterotrophic metabolism require nitrogen and these biotic processes dominate inorganic nitrogen retention in streams. Factors that affect the relative balance of autotrophic and heterotrophic metabolism indirectly control inorganic nitrogen uptake.

Keywords: biome, metabolism, nitrogen, stable isotope, transient storage

\section{Introduction}

In North America, the latitudinal temperature gradient and east-west moisture gradient create well defined terrestrial biomes which, in turn, define many of the characteristics of streams in these regions. Ross (1963) noted that many aquatic insect distributions are related to terrestrial biomes, and Hynes (1975), Vannote et al. (1980), Gregory et al. (1991) and others have emphasised the links between terrestrial vegetation and many aspects of stream structure and function. This study addresses the linkages of terrestrial biomes to three related aspects of stream function: nitrogen dynamics, metabolism and transient storage.

\section{Nitrogen dynamics}

Nitrogen is an essential and frequently limiting nutrient in terrestrial, freshwater and, especially, marine ecosystems. Atmospheric deposition and direct additions of anthropogenic nitrogen as well as agricultural activities have caused major changes to terrestrial nitrogen dynamics and have led to large increases in stream water concentrations of dissolved inorganic nitrogen (DIN) (e.g. Bormann et al., 1968; Aber et al., 1989). High DIN concentration can lead to eutrophication of downstream lakes and coastal marine ecosystems (e.g. Vitousek et al., 1997).

Nitrogen cycles in streams just as in other ecosystems: DIN is immobilised by both autotrophic and heterotrophic uptake and is eventually returned to inorganic form by mineralisation. However, because of the constant downstream flux, nitrogen cycles in streams are extended into spirals (Webster \& Patten, 1979), and nitrogen processes in streams can be described in terms of spiraling length, the average distance a nitrogen atom travels as it completes an inorganic to organic to inorganic cycle (Newbold et al., 1981; Elwood et al., 1983). Spiraling length can be divided into two parts, uptake length (inorganic to organic) and turnover length (organic to inorganic). Uptake lengths of nitrogen and other nutrients can be measured by adding inorganic chemicals to streams and measuring the longitudinal decline in water column concentration (e.g. Stream Solute Workshop, 1990) although, because of an enrichment effect, this technique generally overestimates ambient uptake length (Mulholland, Steinman \& Elwood, 1990; Hart, Freeman \& McKelvie, 1992; Mulholland et al., 2002). More accurate determination of spiraling length, including turnover length, requires radioactive or stable isotope tracers (e.g. Newbold et al., 1983; Mulholland et al., 1997; Peterson, Bahr \& Kling, 1997; Hall, Peterson \& Meyer, 1998).

Measuring spiralling of nitrogen in streams is critical to understanding the fate of anthropogenic nitrogen, and a first step is to measure ammonium uptake and to understand factors controlling ammonium uptake. Ammonium is the most labile form of nitrogen. In streams it is rapidly immobilised and can be remineralised or converted to less reactive but more mobile nitrate either by direct nitrification or indirect nitrification via assimilatory uptake and subsequent mineralisation (Peterson et al., 2001). However, recent studies show that a significant portion of immobilised nitrogen remains in organic form (either dissolved or particulate organic nitrogen, DON or PON) and is eventually transported downstream in that form (Dodds et al., 2000; Mulholland et al., 2000; Tank et al., 2000; Hamilton et al., 2001; Wollheim et al., 2001; Merriam et al., 2002). Most nitrogen entering oceans is either DON or PON (Meybeck, 1982). Both DON and PON are considered to be relatively refractory, though recent studies suggest that $2-70 \%$ of DON in large rivers may be bioavailable (Seitzinger \& Sanders, 1997). Also, the 
bioavailability of DON may be enhanced once it enters estuarine and marine waters (Stepanauskas, Edling \& Tranvik, 1999). The bioavailability of PON is unknown, though PON may be the largest component of annual transport of nitrogen from rivers to oceans (Meybeck, 1982). From the perspective of minimising downstream and coastal eutrophication, the most desirable fate of anthropogenic nitrogen would be denitrification. This is the only process that results in permanent removal of nitrogen from aquatic systems. While several studies have demonstrated considerable potential for denitrification in streams (Seitzinger, 1988; Holmes et al., 1996; Martin et al., 2001; Steinhart, Likens \& Groffman, 2001), the role of denitrification in streams is still poorly known.

\section{Metabolism}

Stream metabolism includes autotrophic primary production and autotrophic and heterotrophic respiration. Comparisons of metabolism in various biomes (Minshall, 1978; Minshall et al., 1983; Lamberti \& Steinman, 1997; Mulholland et al., 2001) have demonstrated clear relationships between these processes and terrestrial vegetation. Stream metabolism can be supported by both allochthonous and autochthonous energy sources, and results from various studies suggest that there is some compensation between energy inputs to streams. Where allochthonous inputs are low, light and autochthonous production can be high but, where riparian trees provide substantial allochthonous inputs, their shade also limits autochthonous production.

Shifting metabolic activity resulting from changes in the influence of terrestrial vegetation is a major tenet of the River Continuum Concept (Vannote et al., 1980). This downstream trend was clearly demonstrated for stream sites ranging from first to ninth order in Quebec (Naiman, 1983; Conners \& Naiman, 1984). A metabolic shift can also be seen following logging. Removal of the riparian canopy allows a pulse of autochthonous production, but rapid closure of the canopy then returns the stream to reliance upon allochthonous materials (e.g. Webster et al., 1983). A similar metabolic pattern is evident when stream metabolism is compared among biomes. In both coniferous and deciduous forest biomes, riparian forests provide allochthonous inputs and limit primary production by reducing available light. In arid areas where low rainfall and flash floods limit riparian trees and allochthonous inputs to streams, very high rates of primary production have been measured (e.g. Minshall, 1978; Cushing \& Wolf, 1984; Grimm, 1987). In boreal, polar and high altitude areas, however, low temperature and, perhaps, low nutrient concentrations result in both low allochthonous and autochthonous inputs (e.g. Naiman \& Link, 1997).

\section{Transient storage}

While there is clear evidence that stream metabolism is tied to the terrestrial setting, the physical characteristics of the channel may also alter metabolism and nutrient dynamics. In some streams significant metabolism occurs within the hyporheic zone (Grimm \& Fisher, 1984; Pusch \& Schwoerbel, 1994; Naegeli \& Uehlinger, 1997; Fellows, Valett \& Dahm, 2001), and variable dissolved oxygen concentration allows a variety of biogeochemical processes (e.g. Triska et al., 1989; Baker, Valett \& Dahm, 2000). Also, where there is significant exchange of water between surface and subsurface zones, the hyporheic zone may delay downstream transport of water (Morrice et al., 1997). This transient storage (Bencala, 1983), the routing of water along flow paths moving much more slowly than the average velocity in the stream channel, is largely controlled by bed form, channel slope and streambed particle characteristics. Recent work suggests that transient storage can also be attributed in part to surface features of streams including backwaters and pools (Lancaster \& Hildrew, 1993; Harvey \& Wagner, 2000).

\section{Nitrogen dynamics, metabolism and transient storage}

Stream nitrogen dynamics, metabolism and transient storage are interconnected in a variety of ways. For example, a connection between stream metabolism and dissolved inorganic nitrogen uptake is evident for autochthonous production; algal anabolic processes require assimilative uptake of DIN. Heterotrophic bacteria and fungi also immobilise inorganic nitrogen, but their influence on water column DIN may be less because they can also obtain nitrogen from organic substrates. Terrestrial vascular plant leaves are generally deficient in nitrogen relative to microbial needs, however, and DIN uptake can be dominated by heterotrophic uptake and is related to the abundance 
of leaves in the stream (Tank et al., 2000; Webster et al., 2000).

There is also a connection between transient storage and nitrogen dynamics in streams. The hyporheic zone is actively involved in the processing and transformation of nitrogen (e.g. Jones \& Holmes, 1996; Duff \& Triska, 2000), and several studies have shown that hyporheic processes impact whole-stream nitrogen dynamics (Valett et al., 1994; Jones, Fisher \& Grimm, 1995). There are suggestions that hyporheic processes, and their effect on stream DIN uptake, may be related to characteristics of the transient storage zone (Valett et al., 1996, 1997; Mulholland \& DeAngelis, 2000).

Recent studies by Alexander, Smith \& Schwarz (2000) and Peterson et al. (2001) have demonstrated that headwater streams are efficient in transforming DIN and suggest that disturbances in small streams may greatly influence downstream transport of DIN. Using tracer measurements of DIN uptake, Peterson et al. (2001) estimated that small, headwater streams export as DIN less than half of the input of DIN from their catchments. Our current study builds on that previous work. Our objective was to relate inter-biome variability in ammonium uptake in streams to various physical, chemical and biological processes based on measurements made as part of the Lotic Intersite Nitrogen eXperiment (LINX). Data were collected from 11 streams (Fig. 1) ranging from the North Slope of Alaska to Puerto Rico and from desert to rain forest (Table 1). These sites were chosen to represent the biomes of North America and because of a long history of prior research in most cases, which provides background for our short-term studies. Our intent was to select study streams over wide ranges of autotrophic to heterotrophic metabolism and low to high transient storage. Most sites were located where there has been relatively little direct anthropogenic disturbance.

\section{Methods}

Site descriptions

Ball Creek is a second order stream at Coweeta Hydrologic Laboratory, Macon County, North Caro-

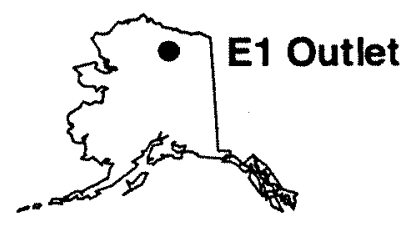

\section{LINX}

\section{Lotic Intersite Nitrogen eXperiment}

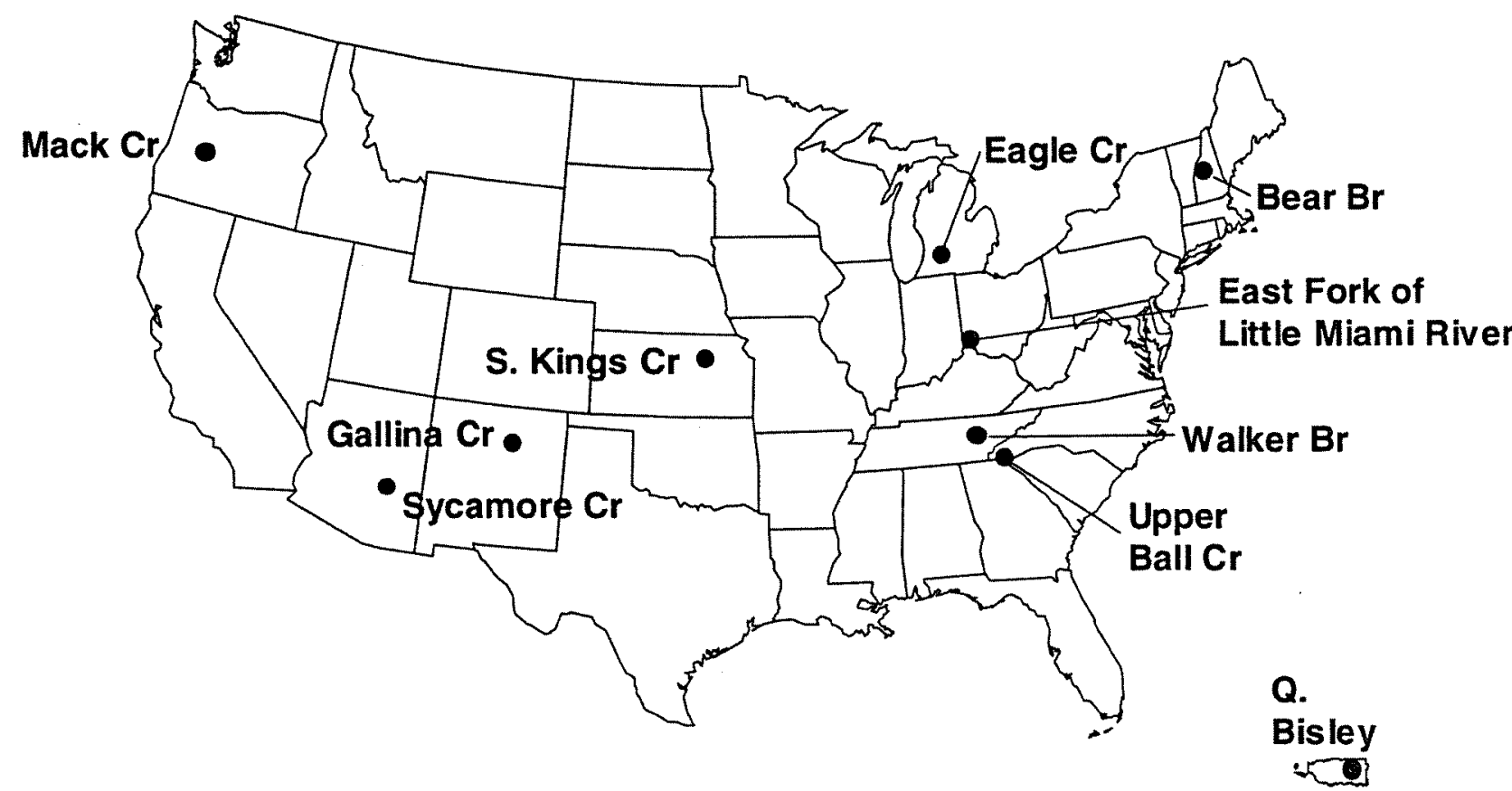

Fig. 1 Stream sites used in this study. 


\begin{tabular}{|c|c|c|c|c|c|c|c|c|c|c|}
\hline Stream & Biome & $\begin{array}{l}\text { PAR } \\
(\text { mol m } \\
\text { (day of } \\
\text { metabolism) }\end{array}$ & $\begin{array}{l}\text { Temperature } \\
\left({ }^{\circ} \mathrm{C}\right) \text { (day of } \\
\text { nitrogen } \\
\text { uptake) }\end{array}$ & $\begin{array}{l}\text { Discharge } \\
\left(\mathrm{L} \mathrm{s}^{-1}\right)\end{array}$ & $\begin{array}{l}\text { Depth } \\
(\mathrm{cm})\end{array}$ & $\begin{array}{l}\text { Width } \\
\text { (m) }\end{array}$ & $\begin{array}{l}\text { Reach } \\
\text { length } \\
\text { (m) }\end{array}$ & $\begin{array}{l}\text { Gradient } \\
\left(\mathrm{mm}^{-1}\right)\end{array}$ & $\begin{array}{l}\text { Lateral } \\
\text { inflow } \\
\left(\% \mathrm{~m}^{-1}\right)\end{array}$ & $\begin{array}{l}\text { Manning } \\
\text { roughness }\end{array}$ \\
\hline $\begin{array}{l}\text { Ball Creek, North Carolina (BCNC) } \\
\left(35^{\circ} 03^{\prime} \mathrm{N}, 83^{\circ} 26^{\prime} \mathrm{W}\right)\end{array}$ & Southern Deciduous Forest & 0.8 & 8.0 & 42.7 & 10.2 & 2.7 & 115 & 0.170 & 0.098 & 0.83 \\
\hline $\begin{array}{l}\text { West Fork Walker Branch, Tennessee } \\
\left(\text { WBTN) }\left(35^{\circ} 58^{\prime} \mathrm{N}, 84^{\circ} 17^{\prime} \mathrm{W}\right)\right.\end{array}$ & Southern Deciduous Forest & 12.6 & 12.2 & 9.1 & 4.9 & 3.2 & 75 & 0.035 & 0.085 & 0.28 \\
\hline $\begin{array}{l}\text { Sycamore Creek, Arizona (SCAZ) } \\
\left(33^{\circ} 45^{\prime} \mathrm{N}, 111^{\circ} 30^{\prime} \mathrm{W}\right)\end{array}$ & Sonoran Desert & 50.0 & 19.5 & 66.0 & 8.8 & 6.2 & 120 & 0.003 & 0.140 & 0.05 \\
\hline $\begin{array}{l}\text { Bear Brook, New Hampshire (BBNH) } \\
\left(43^{\circ} 56^{\prime} \mathrm{N}, 71^{\circ} 45^{\prime} \mathrm{W}\right)\end{array}$ & Northern Deciduous Forest & 2.2 & 13.0 & 4.4 & 9.8 & 2.2 & 100 & 0.140 & 0.230 & 3.80 \\
\hline $\begin{array}{l}\text { Gallina Creek, New Mexico } \\
\text { (GCNM) }\left(36^{\circ} 35^{\prime} \mathrm{N}, 105^{\circ} 35^{\prime} \mathrm{W}\right)\end{array}$ & Montane Coniferous Forest & 6.8 & 10.1 & 5.7 & 3.9 & 1.3 & 77 & 0.120 & 0.000 & 0.48 \\
\hline $\begin{array}{l}\text { Quebrada Bisley, Puerto Rico } \\
\text { (QBPR) }\left(18^{\circ} 19^{\prime} \mathrm{N}, 65^{\circ} 45^{\prime} \mathrm{W}\right)\end{array}$ & Tropical Forest & 0.3 & 21.9 & 12.6 & 12.8 & 4.7 & 140 & 0.133 & 0.141 & 1.66 \\
\hline $\begin{array}{l}\text { Kings Creek, Kansas (KCKS) } \\
\left(39^{\circ} 05^{\prime} \mathrm{N}, 96^{\circ} 35^{\prime} \mathrm{W}\right)\end{array}$ & Tall Grass Prairie & 38.0 & 10.5 & 10.9 & 15.4 & 2.7 & 120 & 0.020 & 0.143 & 0.91 \\
\hline $\begin{array}{l}\text { Eagle Creek, Michigan (ECMI) } \\
\left(42^{\circ} 20^{\prime} \mathrm{N}, 85^{\circ} 20^{\prime} \mathrm{W}\right)\end{array}$ & Northern Deciduous Forest & 18.0 & 20.0 & 263 & 23.0 & 6.1 & 450 & 0.0025 & 0.000 & 0.06 \\
\hline $\begin{array}{l}\text { Mack Creek, Oregon (MCOR) } \\
\left(44^{\circ} 12^{\prime} \mathrm{N}, 122^{\circ} 09^{\prime} \mathrm{W}\right)\end{array}$ & Coniferous Forest & 3.8 & 13.3 & 87.4 & 15.5 & 6.0 & 200 & 0.098 & 0.083 & 1.21 \\
\hline $\begin{array}{l}\text { E1 Outlet, Alaska (E1AK) } \\
\left(68^{\circ} 38^{\prime} \mathrm{N}, 149^{\circ} 38^{\prime} \mathrm{W}\right)\end{array}$ & Arctic Tundra & $\mathrm{nm}$ & 10.5 & 16.7 & 12.0 & 1.5 & 269 & 0.055 & 0.000 & 0.07 \\
\hline $\begin{array}{l}\text { East Fork LittleMiami River, Ohio } \\
(\mathrm{MROH})\left(39^{\circ} 04^{\prime} \mathrm{N}, 84^{\circ} 11 \mathrm{~W}\right)\end{array}$ & Deciduous Forest & 26.2 & $\mathrm{~nm}$ & 849 & 23.0 & 14.6 & 1,000 & 0.02 & $\mathrm{~nm}$ & 0.21 \\
\hline
\end{tabular}

$\mathrm{nm}=$ not measured. 
lina. The catchment is mature mixed deciduous forest with a heavy streamside canopy of rhododendron (Rhododendron maximum L.). Stream water has very low nutrient concentrations and the bed substratum is mixed sand-gravel-pebble with some bedrock outcrops. Research at this site was conducted during autumnal leaf fall. Details of the study at Ball Creek were published by Tank et al. (2000).

The West Fork of Walker Branch is located on the U.S. Department of Energy's Oak Ridge National Environmental Research Park, Tennessee. This reach of Walker Branch is first order and spring fed and has relatively high alkalinity $\left(2-3 \mathrm{mEq} \mathrm{L}^{-1}\right)$ and $\mathrm{pH}$ (approximately 8.0 ), reflecting the underlying dolomitic bedrock, although nutrient concentrations are low in this cobble and bedrock dominated stream. The catchment is deciduous forest dominated by oaks (Quercus spp.), hickories (Carya spp.) and red maple (Acer rubrum L.). Research was conducted in early spring, and Mulholland et al. (2000) reported findings from that study.

Sycamore Creek is a warmwater, sunlit stream in the northern Sonoran Desert of central Arizona. During the study (April-June), Sycamore Creek exhibited declining discharge (from ca. $70-20 \mathrm{~L} \mathrm{~s}^{-1}$ ) following the winter high-flow period, increasing temperature $\left(19-25^{\circ} \mathrm{C}\right)$ and rapid growth of algae. By mid-June the study reach had extensive green algal mats [Cladophora glomerata (L.) Kütz] and very low flow. The study reach (Holmes, Fisher \& Grimm, 1994) was a fine-gravel run in an active channel of ca. $15 \mathrm{~m}$ width bordered by riparian vegetation of ash (Fraxinus velutina Torr.), willow (Salix goodingii Ball.), cottonwood (Populus fremonti S. Wats.) and mesquite (Prosopis juliflora (Sw.) DC.).

Bear Brook is a small, high-gradient stream, located in the Hubbard Brook Experimental Forest, Campton, New Hampshire. Its catchment is south-facing and vegetation is dominated by American beech (Fagus grandifolia Ehrh.), yellow birch (Betula alleghaniensis Brit.) and sugar maple (Acer saccharum Marsh.). The study site drains Hubbard Brook's catchments 5 and 6. During this study (late June and July 1997), the overstory vegetation was fully developed and the entire stream reach was heavily shaded. The study area was part of the reach studied by Fisher \& Likens (1973).

In New Mexico, the study reach was located on Gallina Creek, a headwater montane stream, located in the Sangre de Cristo Mountains of Carson National Forest in northern New Mexico at an altitude of $2591 \mathrm{~m}$ (Crenshaw, Valett \& Tank, 2002). Parent lithology is granite/gneiss (Valett et al., 1996) and catchment vegetation consists of Ponderosa pine (Pinus ponderosa Laws.), Douglas fir (Psuedotsuga menziesii Franco), alder (Alnus sp.) and aspen (Populus tremuloides Michx.). The stream substratum ranges from cobbles to boulders and the channel has alternating riffles and small pools. The average gradient of the $200-\mathrm{m}$ study reach was $>10 \%$. This site was studied in early autumn (August-October).

Quebrada Bisley is a second order stream at the Luquillo Experimental Forest in northeastern Puerto Rico, which was studied in January-March. Catchment vegetation is dominated by tabonuco (Dacryodes excelsa Vahl.) forest, and palms and bamboo are common in the riparian zone. The high-gradient stream is heavily shaded and has a substratum dominated by bedrock, boulders and cobble. Details of this study were reported by Merriam et al. (2002).

Kings Creek is located on upland prairie at Konza prairie Biological Station in the Flint Hills of Kansas. The experimental reach on South Kings Creek is intermittent but flowed continuously during this study (April-May). This reach has limited tree cover in the riparian zone, dense prairie grass cover to the stream banks and substantial inputs of solar radiation. Part of the catchment was burned just prior to the study, and the area was grazed by bison throughout the study. Detailed description of the study reach was published by Dodds et al. (2000).

Eagle Creek is a second order tributary of the Kalamazoo River in southwestern Michigan. It drains a catchment of secondary deciduous forest and successional fields lying primarily within the Fort Custer State Recreation Area. There is a small impoundment $1200 \mathrm{~m}$ upstream of the study site and, between this impoundment and the study site, the stream passes through wetlands filled with emergent vegetation and several small beaver impoundments. Most of the study reach was shaded by deciduous forest during the June-August study. Hamilton et al. (2001) described results of the study on Eagle Creek.

Mack Creek is a third-order tributary of Lookout Creek located within the H.J. Andrews Experimental Forest in the western Cascade Mountains of Oregon. The upstream basin is dominated by $400-500$-year-old 
coniferous trees, predominantly Douglas fir, western hemlock [Tsuga heterophylla (Rafn.) Sarg.] and western red cedar (Thuja plicata Donn). Streamside vegetation has a deciduous component, including two species of maple (Acer spp.) and many species of shrubs and herbs. Mack Creek has been the site of numerous stream studies (e.g. Minshall et al., 1983). This study was done during July and August.

E1 Outlet is a second order stream that enters the eastern shore of Toolik Lake on the North Slope of arctic Alaska. This stream drains an area of moist tussock tundra and partially exposed fell fields. The study reach began below a waterfall and extended downstream $128 \mathrm{~m}$ to a road crossing about $137 \mathrm{~m}$ above the lake edge. The reach is steep and dominated by large cobbles, which form nearly continuous riffles with few intervening pools. Riparian vegetation along this tundra stream is restricted to grasses and low forbs, thus light penetration is unimpeded by shading. Research at this site was done in late June and July when sunlight duration was maximal. Additional information about this site is included in the study by Wollheim et al. (2001).

The East Fork Little Miami River in southeastern Ohio drains a basin of approximately 120000 ha and is a major tributary to the Little Miami River [United States Geological Survey (USGS), 2000]. The northern and eastern portions of the catchment are largely agricultural, and the southwestern portion of the catchment is extensively urbanized. The field site for this study was located about $8 \mathrm{~km}$ downstream from Harsha Lake reservoir. At this location, the river is split by an island that is approximately $1 \mathrm{~km}$ in length, providing a 1-km stretch of river with baseflow of about $850 \mathrm{~L} \mathrm{~s}^{-1}$ that was used for this study. The sampling site is comprised of alternating sequences of riffles and shallow pools or glides. Riffles have mainly a cobble and gravel substratum, pools are silty and wood is sparse in this stretch of the channel. This site was studied in August-October.

Each of these streams was the site of a long-term (3542 days) ammonium- ${ }^{15} \mathrm{~N}$ addition (Peterson et al., 2001). Results presented in this paper are based on data collected 2 weeks prior to the ${ }^{15} \mathrm{~N}$ addition (physical and biological characteristics), the first day of the ${ }^{15} \mathrm{~N}$ addition (chemical characteristics and ammonium uptake) and during the ${ }^{15} \mathrm{~N}$ addition (light and metabolism).

\section{Physical and chemical characteristics}

Basic physical measurements were made at each site including temperature (first day of ${ }^{15} \mathrm{~N}$ addition), stream width (5-m intervals along the study reach) and stream depth (5-10 measurements per cross section). We measured photosynthetically active radiation (PAR) during metabolism measurements using a quantum sensor (LiCor 190SA, Lincoln, NB, USA) located within $20 \mathrm{~cm}$ of stream water level on the stream bank at one representative location. At each site, water samples were collected on the first day of ${ }^{15} \mathrm{~N}$ addition and analysed for inorganic nitrogen $\left(\mathrm{NH}_{4}-\mathrm{N}\right.$ and $\mathrm{NO}_{3}-\mathrm{N}$ ) and soluble reactive phosphorus (SRP) using standard colorimetric methods [American Public Health Association (APHA), 1992] or ion chromatography.

\section{Hydraulic characteristics}

Hydraulic characteristics were determined several days prior to the start of the ${ }^{15} \mathrm{~N}$ additions using short-term conservative solute addition experiments. A known concentration of conservative solute was released at a constant rate using a peristaltic pump for a period of $1-5 \mathrm{~h}$, and measurements were made downstream to determine the concentration and timing of the passage of the solute pulse (e.g. Stream Solute Workshop, 1990; Webster \& Ehrman, 1996). Chloride was used as the conservative solute at all sites except Eagle Creek and EI Outlet where we used bromide. Solute concentrations were measured at one to four stations ranging from 20 to $450 \mathrm{~m}$ downstream of the release site, beginning at the start of the injection and continuing until increases in the in-stream concentration of conservative solutes were no longer detected. At most sites, stream concentrations were measured directly with ion specific electrodes or conductivity meters, which were calibrated in the field with standard solutions. At Eagle Creek and E1 Outlet, water samples were collected at frequent intervals (1-5 min) and analysed for bromide in the laboratory using ion chromatography.

Data from the conservative solute injections were analysed using an advection-dispersion model with transient storage and inflow (Bencala \& Walters, 1983). The data were initially fit by trial and error (Bencala, 1993) using all stations. Then the data from 
the station with the best fit were used in the parameter estimation program of Hart (1995) to determine the parameter values that best fit the data. Damkohler numbers, which indicate the adequacy of the data for estimating parameter values (Wagner \& Harvey, 1997), ranged from 0.12 (Gallina Creek) to 3.0 (Ball Creek) and 4.0 (Eagle Creek). These values are generally in the range suggested by Wagner \& Harvey (1997) for adequate parameter estimation.

\section{Biological characteristics}

Epilithon, filamentous algae, fine benthic organic matter (FBOM, particles $<1 \mathrm{~mm}$ ) and coarse benthic organic matter (CBOM, wood and leaves $>1 \mathrm{~mm}$ ) standing crops were measured approximately 2 weeks before the start of the ${ }^{15} \mathrm{~N}$ addition. CBOM was measured at 10-12 locations in each stream. We placed a metal cylinder $\left(0.07 \mathrm{~m}^{2}\right)$ into the sediments and removed CBOM (separating it into wood and leaves). CBOM was then dried, weighed, ashed and re-weighed to determine standing stocks. FBOM was sampled by sealing a metal cylinder on the stream bottom, mixing the sediments to $5 \mathrm{~cm}$, pumping stream water and particles into a bucket, measuring total volume, subsampling, filtering onto a GF/F filter (Whatman, Maidstone, UK), drying, weighing, ashing and re-weighing to determine FBOM standing stock in gram ash free dry mass (AFDM) per square metre streambed. Epilithon standing stocks were determined using approximately 12 randomly selected rock scrapings of known area and filtering the epilithon slurry from each rock onto a precombusted, preweighed GF/F filter. Filters were processed as for FBOM. Filamentous algae, where present, were sampled by coring mats and underlying sediments to about $5 \mathrm{~cm}$. Filaments were separated from sediments and dried, weighed, ashed, reweighed and AFDM calculated as above. The carbon and nitrogen content of each material type was analysed using dried and finely ground tissue on a Carlo Erba elemental analyser (Model 1500, Carlo Erba Instruments, Milan, Italy).

\section{Metabolism}

For all but two streams, rates of gross primary production (GPP) and ecosystem respiration (R) were determined using the upstream-downstream diurnal dissolved oxygen change technique (Odum, 1956;
Marzolf, Mulholland \& Steinman, 1994; Young \& Huryn, 1998). These measurements were made under clear to partly cloudy weather conditions and within 3 weeks of the beginning of the ${ }^{15} \mathrm{~N}$ tracer additions in each stream. Exchange of dissolved oxygen with the atmosphere was calculated based on the average oxygen saturation deficit or excess within the study reach and on reaeration rates determined from the decline in dissolved propane concentrations during steady state injections of propane and a conservative tracer (to account for dilution of propane due to groundwater inflow) performed within 1 day of the metabolism measurements. Mulholland et al. (2001) previously published more detailed methods and results of these metabolism measurements. Because of technical problems with the calibration of dissolved oxygen meters, measurements made at Ball Creek were not included in that paper. With the caveat that Ball Creek measurements are questionable, we have included these measurements here for the purpose of exploring factors that may be related to ammonium uptake. Where we have used these data, this caveat is reiterated, and statistical relationships involving metabolism were tested with and without Ball Creek data.

Metabolism was measured at E1 Outlet in Alaska using changes in dissolved oxygen during multiple light-dark cycles in closed-recirculating chambers (Bowden et al., 1992) on three dates in 1997 (16 June, 11 July and 5 August). On each date, representative rocks were collected from six stations within the experimental reach and from two upstream reference sites. Metabolism was not measured in the East Fork Little Miami River.

\section{Ammonium uptake}

Methods for measuring ammonium uptake have been published previously (Mulholland et al., 2000; Peterson et al., 2001). Briefly, we injected ${ }^{15} \mathrm{NH}_{4}\left(10 \%{ }^{15} \mathrm{~N}\right)$ as ${ }^{15} \mathrm{NH}_{4} \mathrm{Cl}$ to increase the $\delta^{15} \mathrm{~N}$ of the stream water ammonium pool to about $500 \%$ while raising the background concentration of ammonium by less than $1 \%$. Eight hours after beginning the injection, two 4 -L water samples were collected at each of seven downstream sites. These samples were filtered and one sample was analysed for ${ }^{15} \mathrm{~N}$ in ammonium (Holmes et al., 1998). The second $4-\mathrm{L}$ sample was used for ${ }^{15} \mathrm{~N}$-nitrate analysis using the same method after 
removing ammonium and converting nitrate to ammonium with DeVarda's Alloy (Holmes et al., 1998).

Removal of ammonium from the water column is reported in three ways: (i) uptake length $\left[S_{W}(\mathrm{~m})\right]$, the average distance an ammonium ion travels in the water column before it is removed or transformed by either biological or physical processes (Newbold et al., 1981); (ii) uptake velocity $\left[V_{f}\left(\mathrm{~mm} \mathrm{~s}^{-1}\right)\right.$, also known as mass transfer coefficient], the theoretical velocity at which ammonium moves from the water column to the stream substratum; and (iii) uptake ( $U$ in $\mathrm{mgN} \mathrm{m} \mathrm{m}^{-2}$ day $^{-1}$ ), the mass flux of ammonium from the water column to the stream substratum per unit area.

Ammonium uptake length was calculated as the inverse of the slope $(k)$ of the line relating the natural $\log$ of tracer ${ }^{15} \mathrm{~N}$-ammonium flux to distance downstream:

$$
S_{w}=\frac{1}{k} .
$$

Background concentrations of ${ }^{15} \mathrm{~N}$-ammonium determined prior to the ${ }^{15} \mathrm{~N}$ addition were subtracted from all measured ${ }^{15} \mathrm{~N}$ values measured after ${ }^{15} \mathrm{~N}$ addition. Ammonium uptake velocity was calculated as stream velocity $(v)$ multiplied by mean stream depth $(d)$ divided by uptake length (Stream Solute Workshop, 1990):

$$
V_{f}=v \frac{d}{S_{w}} \text {. e }
$$

Ammonium uptake was then calculated from uptake velocity and ambient ammonium concentration (C) (Stream Solute Workshop, 1990):

$$
U=V_{f} C \text {. }
$$

\section{Nitrification and nitrate uptake}

In most streams, there was sufficient nitrification to generate measurable ${ }^{15} \mathrm{~N}$-nitrate in the water column during the ${ }^{15} \mathrm{~N}$-ammonium release. For these streams, nitrate uptake and nitrification were estimated from a two-compartment model of tracer ${ }^{15} \mathrm{~N}$-ammonium and ${ }^{15} \mathrm{~N}$-nitrate fluxes (Mulholland et al., 2000; Peterson et al., 2001). We used a least squares technique to determine the nitrification and nitrate uptake rates that best fit the observed ${ }^{15} \mathrm{~N}$-nitrate flux data. In several streams, either the ${ }^{15} \mathrm{~N}$-nitrate values were not meas- urably enriched above natural abundance or too few samples were collected to use the modelling approach to estimate nitrification and nitrate uptake. In these cases, a minimum nitrate uptake rate was determined from short-term solute additions of nitrate to stream water conducted several days prior to the tracer addition (Webster \& Ehrman, 1996).

\section{Statistical analyses}

Most statistical analyses were based on linear regression. We also tested relationships using correlation if no dependent-independent relationship could be assumed. We used transformed data when improved statistical relationships were produced. For this study, $n=11$ unless otherwise noted. If a statistically significant relationship was no longer significant when one site was removed, we did not consider the relationship to be generally significant. All relationships were also tested using the non-parametric Spearman rank correlation, and these results are reported if they differed from the parametric test. We also performed several multiple regressions using the step-wise multiple regression procedure ( $F=4.0$ to enter, $P=0.077$ ).

\section{Results}

\section{Physical and hydraulic characteristics}

Water temperature varied according to latitude (high in Puerto Rico, low in Alaska) and altitude but also reflected the time of year when measurements were made. Temperature ranged from less than $10^{\circ} \mathrm{C}$ in Ball Creek to over $20^{\circ} \mathrm{C}$ in Quebrada Bisley and the East Fork Little Miami River (Table 1). PAR depended on the season of study and the terrestrial biome, ranging from very low in the heavily forested sites (Ball Creek, Quebrada Bisley) to very high at the desert (Sycamore Creek) and grassland (Kings Creek) sites (Table 1).

The 11 streams ranged in width from 1.3 (Gallina Creek) to $14.6 \mathrm{~m}$ (East Fork Little Miami River). All of the streams were relatively shallow with depth ranging from 4 to $23 \mathrm{~cm}$. The 11 streams ranged in discharge from 4 (Bear Brook) to $849 \mathrm{~L} \mathrm{~s}^{-1}$ (East Fork Little Miami River), though most were at the lower end of this range (median $16.7 \mathrm{~L} \mathrm{~s}^{-1}$, Table 1). Velocity (determined from hydraulic simulations, Table 2) was generally related to discharge, though the large 
volume of wood in Mack Creek reduced its velocity, and velocity was relatively rapid in sand-bottomed Sycamore Creek because of the absence of wood or large rocks. We back-calculated the Manning roughness coefficient from depth, slope and velocity and, although this is not the intended use of Manning roughness, it does give a comparative indication of the physical nature of the stream beds. Roughness was generally high compared with typical values (e.g. Chow, 1959), especially in the small higher gradient streams (Table 1). Gradients ranged from 0.0025 (Eagle Creek) to $0.17 \mathrm{~m} \mathrm{~m}^{-1}$ (Ball Creek) (Table 1).

Lateral inflow, the downstream increase in discharge over the study reach, ranged from 0 to $0.23 \% \mathrm{~m}^{-1}$ (Table 1). There was actually a small decrease in discharge along the upper part of the study reach in Gallina Creek.

Dispersion coefficients determined from hydraulic simulations, ranged from 0.02 to 0.50 with a median of $0.11 \mathrm{~m}^{2} \mathrm{~s}^{-1}$ (Table 2). Storage zone exchange coefficients $\left(\alpha\right.$, Table 2) ranged from 0.00005 to $0.00215 \mathrm{~s}^{-1}$, and there were no significant relationships between storage zone exchange coefficients and mean water velocity, discharge or any other measured parameters (regression, $P>0.05$ ).

The size of the transient storage zone $\left(A_{S}\right)$ ranged from 0.004 to $0.342 \mathrm{~m}^{2}$ (Table 2) and was highly dependent on discharge (log-log transform, $r^{2}=0.64$, $P=0.003$ ). Transient storage was also positively related to stream velocity though the relationship was not as strong ( $\left.\log A_{S}, r^{2}=0.34, P=0.06\right)$ and not statistically significant using rank correlation $(r=0.49, P=0.11)$.

To standardise transient storage to stream size, $A_{S}$ was divided by surface water cross-sectional area ( $A=$ width times mean depth) and reported as $A_{S} / A$. This value ranged from less than 0.1 (Gallina Creek and East Fork Little Miami River) to 0.59 (Sycamore Creek) (Table 2). $A_{S} / A$ was not significantly related (linear regression, $P>0.05$ ) to any other measured physical or hydraulic parameters including width, depth, velocity, discharge, Manning roughness, Darcy friction factor or gradient except for a significant rank correlation between $A_{S} / A$ and Reynolds number ( $r=0.62, P=0.048)$.

The following hydraulic factors were calculated from measured or simulation-determined parameters: turnover time in the water column $\left(T_{W}\right)$, turnover time in transient storage $\left(T_{S}\right)$, hydraulic uptake length $\left(S_{H}\right)$ 
and hydraulic retention factor (HRF). Turnover time in the water column was calculated as the inverse of the transient storage exchange coefficient:

$$
T_{W}=\frac{1}{\alpha} .
$$

$T_{W}$ is the average time a parcel of water spends in the water column before it enters transient storage (Mulholland et al., 1994). $T_{W}$ ranged from a few minutes (Ball Creek, Sycamore Creek and Eagle Creek) to several hours (East Fork Little Miami River)

(Table 2).

Similarly, $T_{S}$ is the average time water spends in transient storage before reentering the water column (Mulholland et al., 1994) and was calculated as:

$$
T_{S}=\frac{A_{S}}{A} \times \frac{1}{\alpha} .
$$

$T_{S}$ was as low as $<2 \mathrm{~min}$ (Eagle Creek) and was $<1 \mathrm{~h}$ for all streams (Table 2).

The average distance a parcel of water travels downstream in the channel before entering transient storage can be calculated from $T_{W}$ and water velocity (v) Mulholland et al., 1994):

$$
S_{H}=T_{W} v \text {. }
$$

Packman \& Bencala (2000) described $S_{H}$ as the characteristic channel length for hydraulic exchange between the channel and the storage zone. $S_{H}$ was longest in the largest stream $(5.1 \mathrm{~km}$, East Fork Little Miami River) and shortest in Ball Creek $(53 \mathrm{~m})$ (Table 2). There was a significant relationship between $S_{H}$ and stream depth (linear regression, $\left.r^{2}=0.73, P=0.001\right)$ reflecting the fact that deeper streams have higher velocity and longer $S_{H}$.

Hydraulic retention factor (HRF, Morrice et al., 1997) was calculated as:

$$
\mathrm{HRF}=\frac{A_{S}}{\mathrm{Q}}
$$

where $Q$ is discharge. HRF can be viewed as $A_{S}$ normalised to discharge or as the average time a water parcel spends in transient storage as the water moves $1 \mathrm{~m}$ downstream. It is a function of the frequency of interaction between stream and storage zone water. HRF ranged from 0.35 (East Fork Little Miami River) to 9.1 (Bear Brook) s m$~^{-1}$ (Table 2). HRF was significantly related to Manning roughness $\left(r^{2}=0.85, P<0.001\right)$; however, both parameters are calculated from velocity and are not mathematically independent.

\section{Chemical characteristics}

Ammonium concentrations were generally very low $\left(<5 \mu \mathrm{gN} \mathrm{L}^{-1}\right.$ ) except in Eagle Creek and the East Fork Little Miami River (Table 3). Nitrate concentrations were much more variable, ranging from over $500 \mu \mathrm{gN} \mathrm{L}^{-1}$ in the East Fork Little Miami River and $100 \mu \mathrm{gN} \mathrm{L}^{-1}$ in Quebrada Bisley to less than about $1 \mu \mathrm{gN} \mathrm{L}^{-1}$ in Ball Creek (Table 3). Phosphorus (SRP) was similarly variable, again very high in Quebrada Bisley but very low in several of the other streams (Table 3). Molar N : P ratios (based on nitrate plus ammonium and SRP) ranged from 2.4 in Gallina Creek to 50.3 in Eagle Creek (Table 3).

\section{Biological characteristics}

Among the streams there was great variation in the abundance of algae and vascular plants (Table 4) reflecting the gradient in riparian shading among channels. Epilithon was very high in the unshaded grassland and desert streams (18-76 $\mathrm{g} \mathrm{AFDM} \mathrm{m}^{-2}$ ) and generally low elsewhere $\left(<6 \mathrm{~g} \mathrm{AFDM} \mathrm{m}^{-2}\right)$. Filamentous algae were rare or absent, and therefore not measured at most of the sites, but were abundant at Sycamore Creek where they were 10-fold more abundant than epilithon and, to lesser extent, at Kings Creek.

The FBOM ranged from $2.7 \mathrm{~g} \mathrm{AFDM} \mathrm{m}^{-2}$ in the East Fork Little Miami River to $212 \mathrm{~g} \mathrm{AFDM} \mathrm{m}^{-2}$ in Kings Creek (Table 4). The standing stock of decaying leaves in the streams varied considerably (Table 4) and depended on the nature of the forest canopy, the time of year the study was conducted and the size of the stream. Leaves were abundant in Walker Branch (deciduous forest, early spring measurement) and Ball Creek (deciduous forest, autumn measurement), but other streams had few leaves either because of few or distant riparian trees (E1 Outlet, Kings Creek, Sycamore Creek), the time of year (summer measurements in Bear Brook and Mack (reek) or the lack of leaf retention (Sycamore Creek, Eagle Creek, East Fork Little Miami River).

\section{Metabolism}

Gross primary production was generally low compared with the range that has been reported for various streams (e.g. Lamberti \& Steinman, 1997) with 
Table 3 Nutrient concentrations and nitrogen dynamics in the LINX streams. There was no measurable uptake of nitrate in the study reach of Eagle Creek. Nitrification for Ball Creek is a maximum estimate

\begin{tabular}{|c|c|c|c|c|c|c|c|c|c|c|}
\hline$\because$ & $\begin{array}{l}\text { Date of } \\
\text { nitrogen } \\
\text { uptake } \\
\text { measurement }\end{array}$ & $\begin{array}{l}\mathrm{NH}_{4}-\mathrm{N} \\
\left(\mu g \mathrm{~L}^{-1}\right)\end{array}$ & $\begin{array}{l}\mathrm{NO}_{3}-\mathrm{N} \\
\left(\mu \mathrm{L} \mathrm{L}^{-1}\right)\end{array}$ & $\begin{array}{l}\mathrm{PO}_{4}-\mathrm{P} \\
\left(\mathrm{SRP}, \mu \mathrm{g} \mathrm{L}^{-1}\right)\end{array}$ & $\begin{array}{l}\mathrm{N}: \mathrm{P} \text { ratio } \\
\text { molar } \\
\text { DIN : SRP }\end{array}$ & $\begin{array}{l}\text { Ammonium } \\
\text { uptake } \\
\text { length } \\
\left(S_{w}, m\right)\end{array}$ & $\begin{array}{l}\text { Ammonium } \\
\text { uptake } \\
\text { velocity } \\
\left(V_{f}, \mathrm{~mm} \mathrm{~s}^{-1}\right)\end{array}$ & $\begin{array}{l}\text { Ammonium } \\
\text { uptake } \\
\left(U, \mathrm{gN} \mathrm{m}^{-2} \text { day }^{-1}\right)\end{array}$ & $\begin{array}{l}\text { Nitrate } \\
\text { uptake } \\
\left(\mathrm{gN} \mathrm{m} \mathrm{m}^{-2} \mathrm{day}^{-1}\right)\end{array}$ & $\begin{array}{l}\text { Nitrification } \\
\left(\mathrm{gN} \mathrm{m}^{-2} \text { day }^{-1}\right)\end{array}$ \\
\hline Ball Creek & 4 Nov 96 & 3.0 & 1 & 2 & 4.4 & 27.7 & 0.687 & 0.1781 & 0.008 & 0.009 \\
\hline Walker Branch & 1 Apr 97 & 2.7 & 15.6 & 2.4 & 16.9 & 23.3 & 0.136 & 0.0317 & 0.042 & 0.006 \\
\hline Sycamore Creek & 1 May 97 & 1.9 & 16.8 & 13 & 3.2 & 47.3 & 0.255 & 0.0419 & 0.219 & 0.003 \\
\hline Bear Brook & 17 Jun 97 & 4.0 & 57.4 & 8.1 & 4.0 & 14.0 & 0.119 & 0.0411 & 0.100 & 0.002 \\
\hline Gallina Creek & 26 Aug 97 & 5.2 & 7.5 & 7 & 2.4 & 21.0 & 0.154 & 0.0691 & 0.027 & 0.010 \\
\hline Quebrada Bisley & 15 Jan 98 & 4.2 & 179.3 & 13.2 & 24.4 & 26.4 & 0.144 & 0.0523 & 0.050 & 0.030 \\
\hline Kings Creek & 8 Apr 98 & 2.4 & 3.1 & 2.2 & 5.5 & 57.7 & 0.302 & 0.0626 & 0.022 & 0.007 \\
\hline Eagle Creek & 16 Jun 98 & 23.4 & 28.8 & 2.3 & 50.3 & 1349.5 & 0.034 & 0.0679 & 0.000 & 0.033 \\
\hline Mack Creek & $21 \mathrm{Jul} 98$ & 3.6 & 54.3 & 6 & 21.4 & 54.8 & 0.200 & 0.0621 & 0.034 & 0.028 \\
\hline E1 Outlet & 1 Jul 97 & 1.4 & 35.7 & 1.8 & 45.6 & 40.0 & 0.208 & 0.0252 & 0.168 & 0.010 \\
\hline Little Miami River & 12 Aug 98 & 31.1 & 543.5 & $\mathrm{~nm}$ & $\mathrm{~nm}$ & 474.9 & 0.122 & 0.3290 & 7.299 & 0.109 \\
\hline
\end{tabular}

$\mathrm{nm}=$ not measured.

Table 4 Metabolic and organic parameters of the LINX streams. Epilithon, filamentous algae, FBOM and leaves were measured during the week prior to nitrogen uptake measurements (Table 3)

\begin{tabular}{|c|c|c|c|c|c|c|c|c|}
\hline & $\begin{array}{l}\text { Date of } \\
\text { metabolism } \\
\text { measurement }\end{array}$ & $\begin{array}{l}\text { Gross primary } \\
\text { production } \\
\left(\mathrm{gO}_{2} \mathrm{~m}^{-2} \text { day }^{-1}\right)\end{array}$ & $\begin{array}{l}\text { Ecosystem } \\
\text { respiration } \\
\left(\mathrm{gO}_{2} \mathrm{~m}^{-2} \mathrm{day}^{-1}\right)\end{array}$ & $P: R$ ratio & $\begin{array}{l}\text { Epilithic } \\
\text { biomass } \\
\left(\mathrm{gAFDM} \mathrm{m} \mathrm{m}^{-2}\right)\end{array}$ & 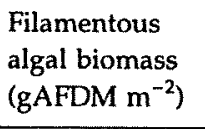 & 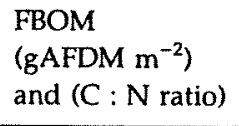 & $\begin{array}{l}\text { Leaves } \\
\left(\mathrm{gAFDM} \mathrm{m} \mathrm{m}^{-2}\right) \\
\text { and }(\mathrm{C}: \mathrm{N} \text { ratio })\end{array}$ \\
\hline Ball Creek & 16 Nov 96 & $0.06 ?$ & $29 ?$ & $0.002 ?$ & 1.26 & $\mathrm{~nm}$ & $43.64(19.6)$ & $62.5(50.2)$ \\
\hline Walker Branch & 10 Apr 97 & 1.2 & 5.4 & 0.22 & 3.8 & $\mathrm{~nm}$ & $197(18.6)$ & $76(47.5)$ \\
\hline Sycamore Creek & 27 May 97 & 15 & 8.3 & 1.8 & 18.28 & 172.3 & $20.46(9.0)$ & $\mathrm{nm}(\mathrm{nm})$ \\
\hline Bear Brook & 27 Jun 97 & 0.2 & 6.9 & 0.03 & 2.66 & 0.0 & $46.5(18.0)$ & $4.2(21.0)$ \\
\hline Gallina Creek & 27 Aug 97 & 0.4 & 6.7 & 0.06 & 3.49 & $\mathrm{~nm}$ & $28.25(18.3)$ & $6.9(23.2)$ \\
\hline Quebrada Bisley & $20 \operatorname{Jan} 98$ & 0.07 & 7.8 & 0.009 & 3.54 & $\mathrm{~nm}$ & $32.23(9.9)$ & $6(32.2)$ \\
\hline Kings Creek & 22 Apr 98 & 1.8 & 2.4 & 0.75 & 75.99 & 2.5 & $212(17)$ & $1.36(29.4)$ \\
\hline Eagle Creek & 6 Jul 98 & 0.8 & 6.4 & 0.12 & 5.84 & $\mathrm{~nm}$ & $164(14.1)$ & $0.9(18.2)$ \\
\hline Mack Creek & 30 Jul 98 & 1.9 & 11 & 0.17 & 2.90 & $\mathrm{~nm}$ & $108.6(27)$ & $0.4(46)$ \\
\hline E1 Outlet & Jun-Aug 1997 & 1.1 & $0.3 ?$ & $3.7 ?$ & $\mathrm{~nm}$ & $\mathrm{~nm}$ & $\mathrm{~nm}(17.1)$ & $3.5(\mathrm{~nm})$ \\
\hline Little Miami River & $\mathrm{nm}$ & $\mathrm{nm}$ & $\mathrm{nm}$ & $\mathrm{nm}$ & 9.5 & $<0.1$ & $2.7(8.5)$ & $0.0(\mathrm{~nm})$ \\
\hline
\end{tabular}

$\mathrm{C}: \mathrm{N}$ ratios are molar. $\mathrm{nm}=$ not measured. $?=$ technical problems or differences in technique. 
the exception of Sycamore Creek where GPP was nearly an order of magnitude higher than any other site (Table 4). Ecosystem respiration, including both autotrophic and heterotrophic respiration, ranged from 5 to $11 \mathrm{~g} \mathrm{O}_{2} \mathrm{~m}^{-2}$ day ${ }^{-1}$ except for low respiration in Kings Creek and E1 Outlet and very high respiration in Ball Creek (Table 4). The high respiration in Ball Creek was probably because of technical problems as noted above, and the low respiration of E1 Outlet may have resulted from the use of chambers to measure metabolism whereas whole-stream methods were used at all other sites. Comparative studies have shown that chamber estimates of respiration are generally lower than those made by whole stream measurements (Bott $e$ t al., 1978, 1997; Dodds \& Brock, 1998; Uzarski, 1999). P: R ratios suggest that metabolism in most of the streams was dominated by respiration of allochthonous organic matter, except in Sycamore Creek and E1 Outlet (Table 4). Using data from eight of the sites, Mulholland et al. (2001) found that GPP was strongly related to PAR and SRP concentration, and these two variables explained $90 \%$ of the variation among sites. Ecosystem respiration was related to SRP and transient storage zone size and, together, these variables explained $73 \%$ of the variation among sites. Ecosystem respiration and GPP were not significantly correlated.

\section{Ammonium uptake}

Uptake length for ammonium ranged from $14 \mathrm{~m}$ (Bear Brook) to $1.3 \mathrm{~km}$ (Eagle Creek) (Table 3). As has been shown previously (Peterson et al., 2001), uptake lengths were significantly related to discharge (Fig. 2a; $\log$-log regression, $r^{2}=0.71, P=0.001$ ) and water velocity (linear regression, $r^{2}=0.61, P=0.004$ ). We found no significant relationships between uptake length (or log uptake length) and any other hydraulic parameter, including $A_{S} / A, S_{H}$ or hydraulic retention factor (Fig. 2), or any metabolic parameter. There was a statistically significant relationship between uptake length and ammonium concentration (Fig. 3; linear regression, $r^{2}=0.60, P=0.005$ ) due to the relatively high ammonium concentration at the two largest streams. However, this relationship was not significant using rank correlation $(r=0.12, P=0.71)$ and, without the two largest streams, the relationship was not significant with parametric statistics (Fig. 3 inset;
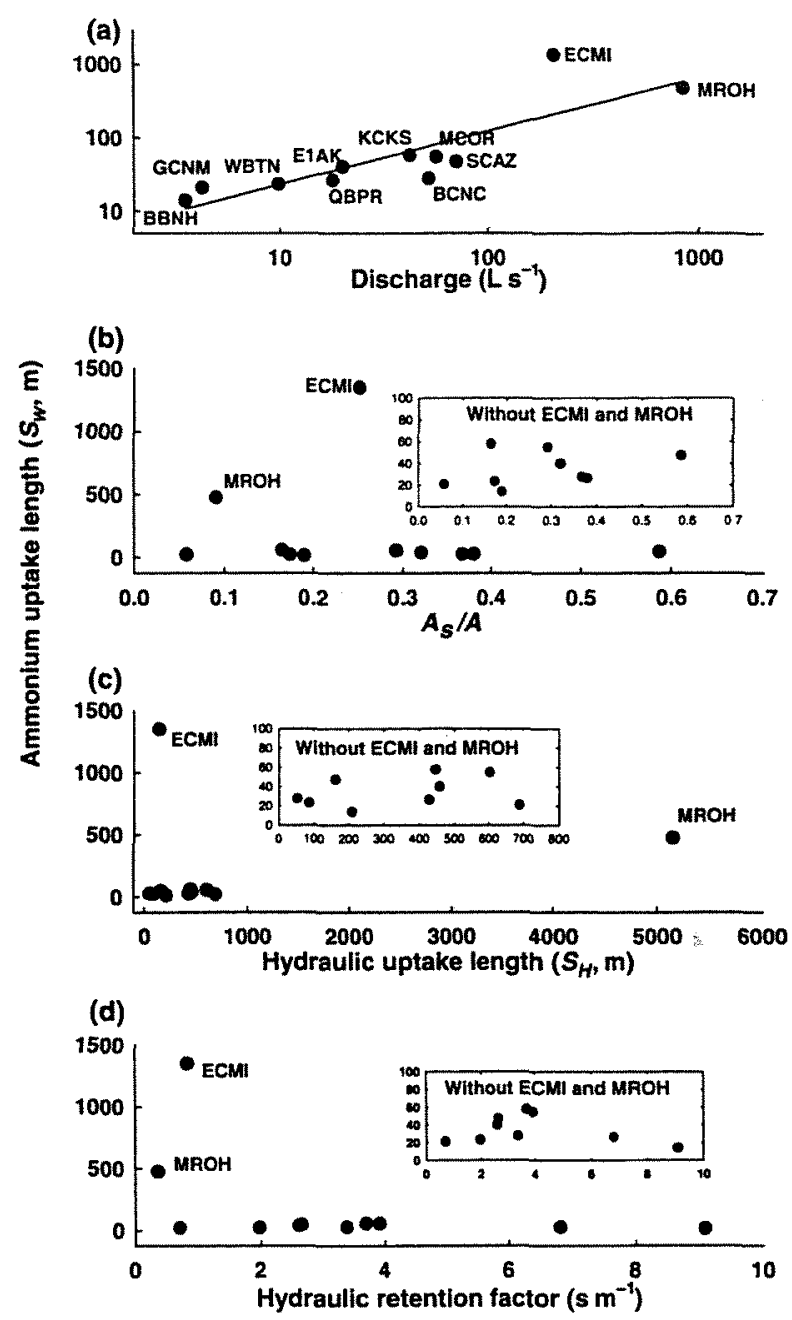

Fig. 2 Ammonium uptake length in relation to various hydraulic factors. Site acronyms are given in Table 1.

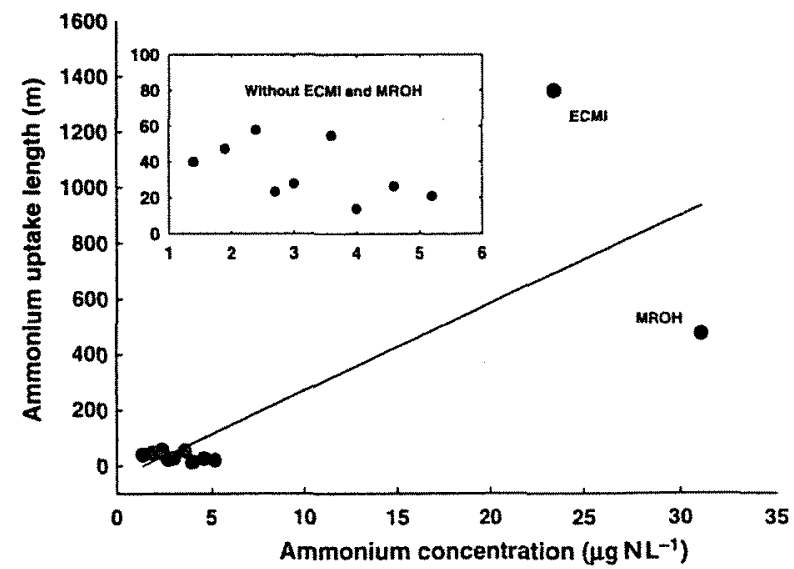

Fig. 3 Relationship between ammonium uptake length and ammonium concentration. Site acronyms are given in Table 1. 


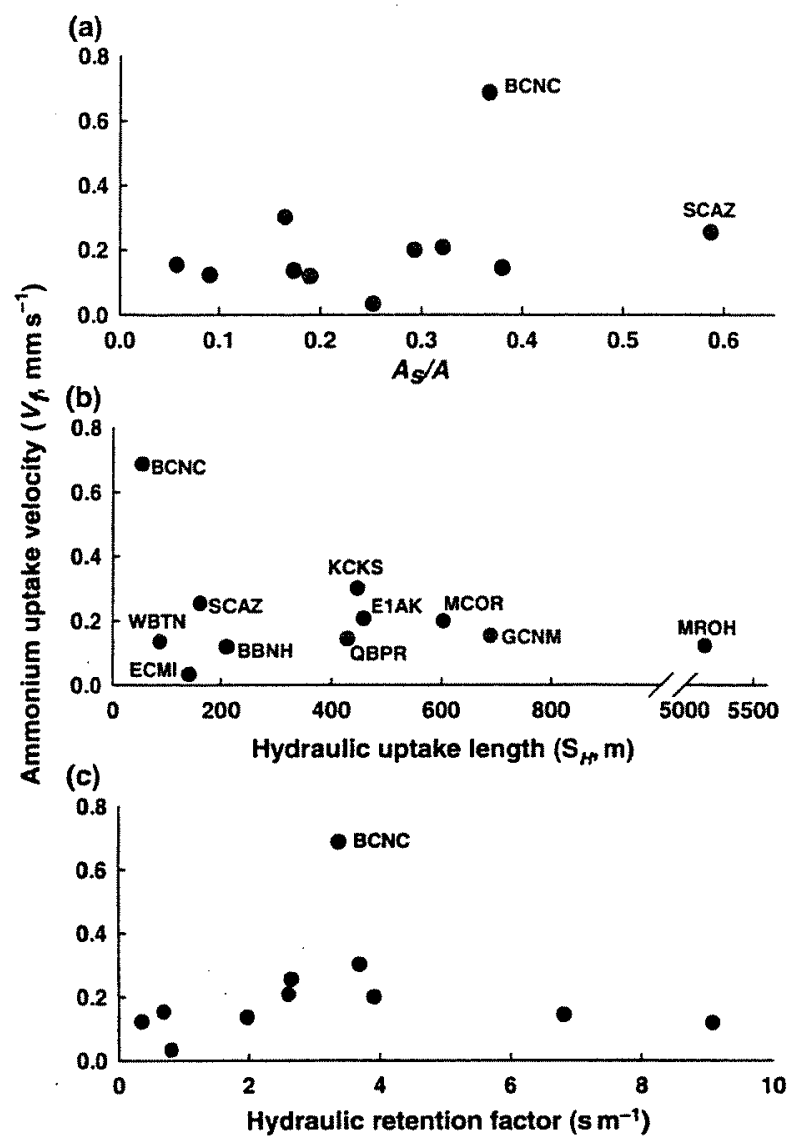

Fig. 4 Ammonium uptake velocity $\left(V_{f}\right)$ in relation to various hydraulic factors. Site acronyms are given in Table 1.

$P=0.14)$. Ammonium uptake length was positively related to ammonium concentration and discharge (multiple regression, $R^{2}=0.88, P<0.001$ ).

Uptake velocity indicates ammonium uptake independent of the effect of discharge. It can be viewed as the rate or velocity at which uptake processes associated with the stream bottom remove ammonium from the overlying water column. Ammonium uptake velocities were generally in a small range of 0.1 to $0.3 \mathrm{~mm} \mathrm{~s}^{-1}$, except for Ball Creek $\left(0.69 \mathrm{~mm} \mathrm{~s}^{-1}\right)$ and Eagle Creek $\left(0.03 \mathrm{~mm} \mathrm{~s}^{-1}\right.$ ) (Table 3). Uptake velocity was not statistically related to any hydraulic (Fig. 4) or metabolic (Fig. 5) parameter (regressions with and without $\log$ transformations and with and without metabolism data from Ball Creek) except for a significant, positive relationship between uptake velocity and ecosystem respiration (Fig. 5b; linear regression, $r^{2}=0.64, P=0.005, n=10$ ). However, this relationship was not significant with rank correlation $(r=0.11$, $P=0.51)$ or with parametric statistics when Ball Creek
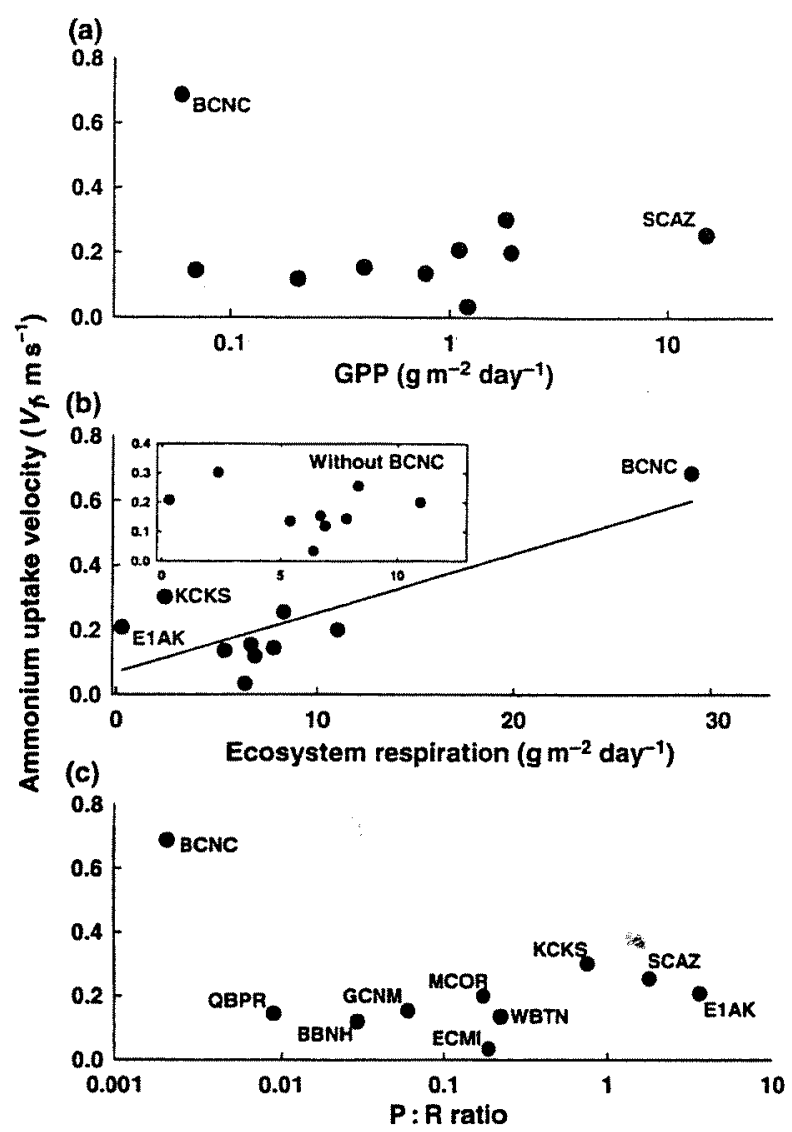

Fig. 5 Relationships between ammonium uptake velocity $\left(V_{f}\right)$ and metabolic parameters. Site acronyms are given in Table 1.

data were removed $(P=0.53)$. There was a marginally significant negative relationship between uptake velocity and ammonium concentration (Fig. 6a; regression of $\log V_{f}$ versus $\left.\mathrm{NH}_{4}, r^{2}=0.35, P=0.054\right)$; however, this relationship was not significant without data from Eagle Creek or when we used rank correlation $(r=-0.69, P=0.016)$. We found a slightly better relationship between uptake velocity and molar $N: P$ ratio (Fig. 6b; regression of $\log V_{f}$ versus $\mathrm{N}: \mathrm{P}$, $r^{2}=0.43, P=0.04$ ) although, again, this relationship was not significant without Eagle Creek data $(P=0.33)$ or with rank correlation $(r=-0.51, P=0.12)$. $\log V_{f}$ was a linear function of respiration ( + ) and ammonium concentration $(-)$ (multiple regression, $R^{2}=0.85$, $P=0.001, n=10$ ), though without Ball Creek data, respiration was not a significant factor.

Ammonium uptake was very high in the East Fork Little Miami River and Ball Creek and relatively low for the other nine streams (Table 3). Uptake was significantly related to discharge (Fig. 7a; log-log 


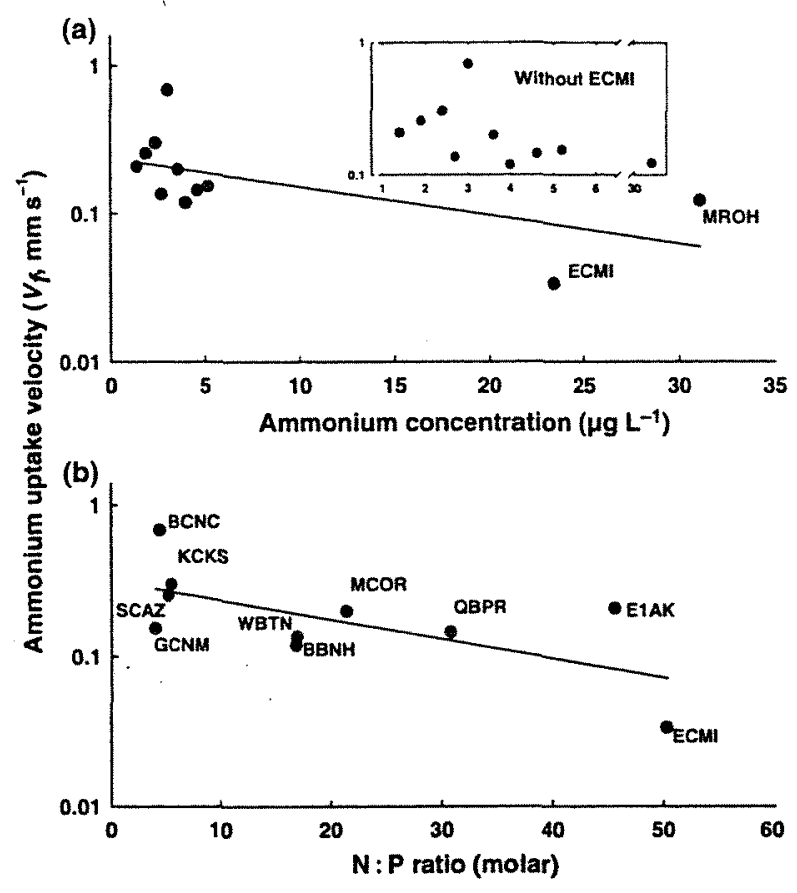

Fig. 6 Relationships between ammonium uptake velocity $\left(V_{f}\right)$ and ammonium concentration and between ammonium uptake velocity and $N: P$ ratio, calculated as the ratio of ammonium plus nitrate to soluble reactive phosphorus. Lines are regression lines. Site acronyms are given in Table 1.

regression, $r^{2}=0.42, P=0.03$ ), reflecting the higher ammonium concentrations of the two largest streams, Eagle Creek and East Fork Little Miami River, but this relationship was not significant with rank correlation ( $r=0.46, P=0.15)$. There was also a significant relationship between ammonium uptake and hydraulic uptake length (Fig. $7 c$; linear regression, $r^{2}=0.75$, $P=0.001$ ), but when the value for East Fork Little Miami River was removed, the relationship was no longer significant (Fig. 7c inset; linear regression, $P=0.46$ ), and it was not significant with rank correlation $(r=0.24, P=0.45$ ). Uptake was not related to any other physical or chemical factor.

Although ammonium uptake was not related to GPP (Fig. 8a; regressions with and without log transformations and with and without data from Ball (reek), there was a significant relationship between ammonium uptake and ecosystem respiration (Fig. $8 \mathrm{~b}$; uptake vs $\log$ respiration, $r^{2}=0.38, P=0.04$ ), although the relationship was not significant when Ball Creek data were removed ( $P=0.15)$ and it was not significant with rank correlation ( $r=0.47, P=0.17$ ). Similarly, the significant relationship between ammonium uptake and $P: R$ (a)
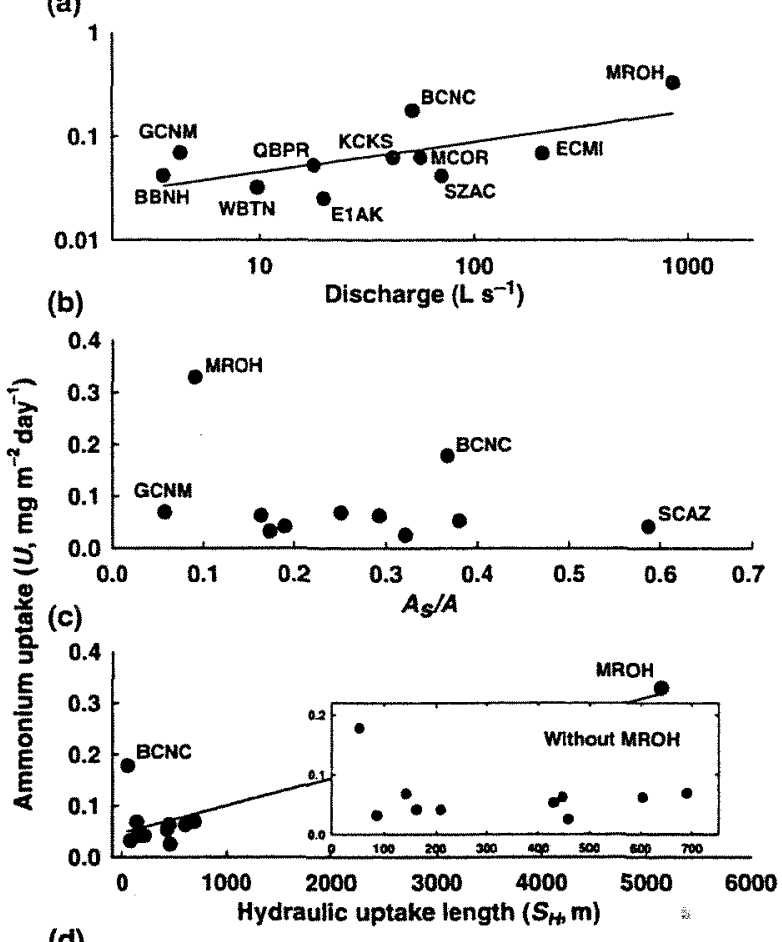

(d)

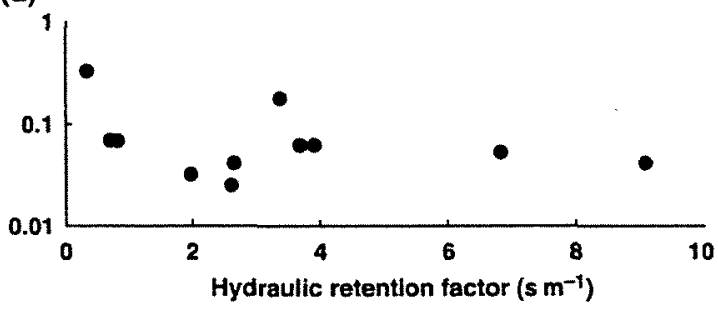

Fig. 7 Ammonium uptake $(U)$ in relation to various hydraulic factors. Site acronyms are given in Table 1.

(Fig. 8c; $\log P: R, r^{2}=0.47, P=0.03$ ) was not significant without Ball Creek data $(P=0.31)$ or with rank correlation $(r=-0.58, P=0.07)$. Using multiple regression, we did not find any linear combination of variables that improved the predictability of ammonium uptake beyond that of single factor models.

\section{Discussion}

Hydraulic characteristics and ammonium uptake

We anticipated that ammonium uptake would be closely linked to hydraulic characteristics of the streams, but this was not realised. While this relationship may exist in a more regional comparison, the variability of hydraulic characteristics of our 11 streams was fairly small and it was apparently 


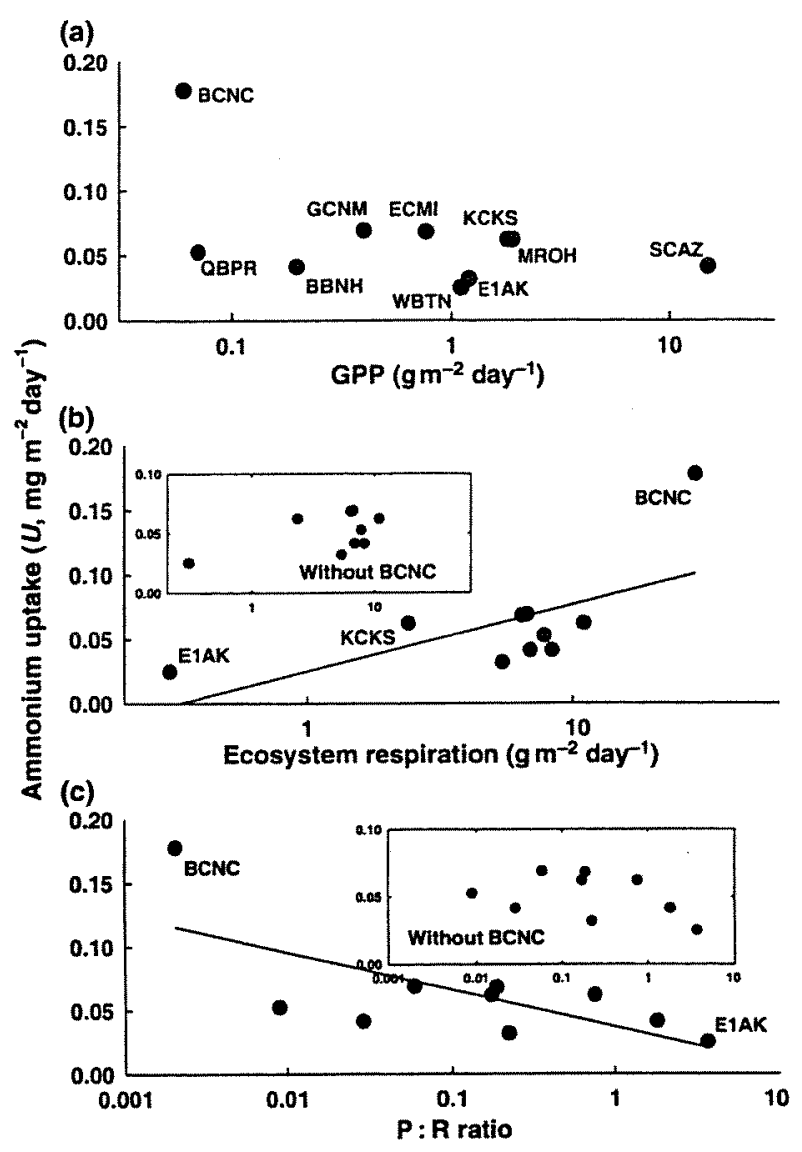

Fig. 8 Relationships between ammonium uptake $(U)$ and metabolic parameters. Site acronyms are given in Table 1.

overwhelmed by the much greater variability of other factors that affect ammonium uptake. The lack of significant relationships between transient storage parameters of LINX streams and our physical measurements suggests that transient storage is not a simple function of easily measured stream characteristics. Rather, transient storage is probably related to other factors, such as the size and variability of streambed material, depth of the streambed, stream topography, streambed porosity and stream shape (D'Angelo et al., 1993; Harvey \& Bencala, 1993; Morrice et al., 1997) as well as physical effects of biotic materials in the streambed such as algae (Mulholland et al., 1994), leaves (Hart et al., 1999) and wood. These factors vary not only from region to region but also from stream to stream and even from reach to reach.

Whatever the physical factors affecting transient storage, the relative importance of transient storage should affect a solute's opportunity to interact with streambed surfaces, the sites of most significant chemical transformations in streams. A variety of studies have demonstrated the importance of surfacesubsurface exchange to chemical dynamics in streams (e.g. Grimm \& Fisher, 1984; Triska et al., 1989; Jones et al., 1995; Holmes et al., 1996). A direct relationship between transient storage and nutrient retention has been demonstrated (Valett et al., 1996; Mulholland et al., 1997). However, Martí, Grimm \& Fisher (1997) found no significant relationship between nitrate uptake and transient storage in Sycamore Creek, and Butturini \& Sabater (1999) concluded that the hyporheic zone did not influence nutrient cycling in the Riera Major. Also, Hall, Bernhardt \& Likens (2002) found that ammonium uptake in streams at Hubbard Brook was only weakly related to transient storage and that no significant relationship existed between phosphorus uptake and transient storage. They suggested that transient storage occurred largely in the water column and not in the hyporheic zone in the small streams they studied and thus had little impact on nutrient dynamics. In the LINX streams, ammonium uptake length $\left(S_{W}\right)$ was generally shorter than hydraulic uptake length $\left(S_{H}\right)$. With the exception of Eagle Creek, the ratio of $S_{H} / S_{W}$ ranged from 1.9 (Ball Creek) to 33 (Gallina Creek) with a median of 11 . Therefore, on average, most ammonium ions were taken up on the benthic surface in the active channel before the water ever entered areas of transient storage such as the hyporheic zone. Thus it is not surprising that we found little relationship between ammonium uptake and measures of transient storage.

\section{Chemical factors and ammonium uptake}

The only significant relationship between ammonium uptake and water chemistry that we found was a positive regression between ammonium concentration and ammonium uptake length. However, this relationship was confounded by the fact that we had nine streams with very low ammonium concentration and two streams with markedly higher concentrations. A better understanding of the relationship between uptake and concentration would require a set of streams with a more complete and extensive range of ammonium concentrations. Using data obtained from experiments with ${ }^{15} \mathrm{~N}$-ammonium and elevated ammonium, Dodds et al. (2002) found linear relationships between the log of ammonium concentration in the water column and both the log of uptake velocity 
and the log of uptake flux. They demonstrated that the uptake flux of ammonium was higher under elevated concentrations than at ambient instream concentrations. While ammonium uptake was apparently saturated at the highest concentrations, a simple model of uptake as a function of concentration appeared to hold over a wide range of ammonium concentrations.

Also, a relationship between ammonium uptake and concentration may be more evident when measurements are made within a single stream or group of similar streams. Mulholland et al. (2000) found that ammonium uptake flux in Walker Branch varied during the study and was highly dependent on concentration. Ammonium is the preferred form of inorganic nitrogen for most biota, but it is often at very low concentrations in streams, thus restricting its uptake and increasing the use of nitrate as an alternative source of nitrogen (Mulholland et al., 2000).

\section{Biological nitrogen demand and inorganic nitrogen uptake}

Though we found no generally significant relationships between ammonium uptake and any single or linear combination of measurements of biological characteristics, this approach does not account for the multiple mechanisms of nitrogen uptake in streams. Another approach is to develop an estimate of nitrogen demand from our understanding of stream metabolism in an attempt to address relationships between carbon metabolism and nitrogen uptake.

Nitrogen is removed from stream water by autotrophic uptake, by heterotrophic immobilisation by microbes degrading organic substrates deficient in nitrogen and by denitrification. Neither nitrification of ammonium nor dissimilatory nitrate reduction to ammonium result in a net loss of nitrogen. Autotrophic assimilation should be proportional to net primary production, and heterotrophic immobilisation should be related to the production of heterotrophic microbes and the nitrogen content of their substrate. The role of denitrification in streams is not well known, but it is probably small in most well-aerated streams with relatively low nitrate concentrations (Holmes et al., 1996; Martin et al., 2001; Kemp \& Dodds, 2002).

To quantify autotrophic nitrogen demand, we made the following calculations. First, we estimated net primary production as $70 \%$ of gross primary production, which is higher than the commonly used $50 \%$ but probably more reasonable for attached algae (Graham, Kranzfelder \& Auer, 1985; Hill, Mulholland \& Marzolf, 2001). We used a photosynthetic quotient (PQ, the molar ratio of $\mathrm{O}_{2}$ evolved to $\mathrm{CO}_{2}$ fixed) of 1.2 (Wetzel \& Likens, 2000) to convert $\mathrm{O}_{2}$ production to carbon fixation. We then used a $\mathrm{C}: \mathrm{N}$ molar ratio of 12 (Grimm, 1985; Dodds \& Priscu, 1990) to convert carbon fixation to nitrogen demand. We used this $C: N$ value for pure, actively-growing algae rather than the $C: N$ ratios of samples taken in our study as these samples also generally contained senescent algae and non-algal material.

Similarly, we estimated heterotrophic nitrogen demand from respiration measurements. We calculated heterotrophic respiration as ecosystem respiration minus autotrophic respiration ( $30 \%$ GPP) and minus oxygen use by nitrification ( 2 moles $\mathrm{O}_{2}$ per mole $\mathrm{N}$ oxidized). Respiration was converted from oxygen to carbon with a respiratory quotient $\left(\mathrm{RQ}\right.$, moles $\mathrm{CO}_{2}$ evolved / moles $\mathrm{O}_{2}$ consumed) of 0.85 (Bott, 1996), and we calculated heterotrophic production as 0.28 times respiration (Cole \& Pace, 1995). Finally, we calculated the nitrogen demand of this production using a molar $C: N$ ratio of 5 (Fenchel, King \& Blackburn, 1998) and subtracted from this the nitrogen available from the substrate assuming that respiration was fuelled by the dominant form of detritus in each stream (leaf $C: N$ for Ball Creek and Walker Branch, FBOM C:N for Sycamore Creek, Kings Creek, Eagle Creek, Mack Creek and E1 Outlet and intermediate $\mathrm{C}: \mathrm{N}$ for other streams). We explored the effects of independently doubling or halving algal and microbial $\mathrm{C}: \mathrm{N}$ ratios, and we used NPP/GPP values ranging from 50 to $77 \%$, microbial production/respiration ranging from 0.2 to 0.4 and the fraction of substrate nitrogen used by heterotrophic microbes ranging form 0 to $100 \%$ to establish sensitivity to values that are not well known. Our conclusions are robust with respect to these ranges of parameter values except as noted below.

Our calculated nitrogen demand was very similar to measured assimilative nitrogen uptake (total nitrogen uptake minus nitrification) except for two streams, Ball Creek and E1 Outlet (Figs 9 and 10). For Ball Creek, calculated nitrogen demand was almost entirely heterotrophic and more than twice the measured uptake. The very high estimate of heterotrophic demand for Ball Creek reflects uncertainty in the metabolism measurements for this site. Based on measurements made in other years 


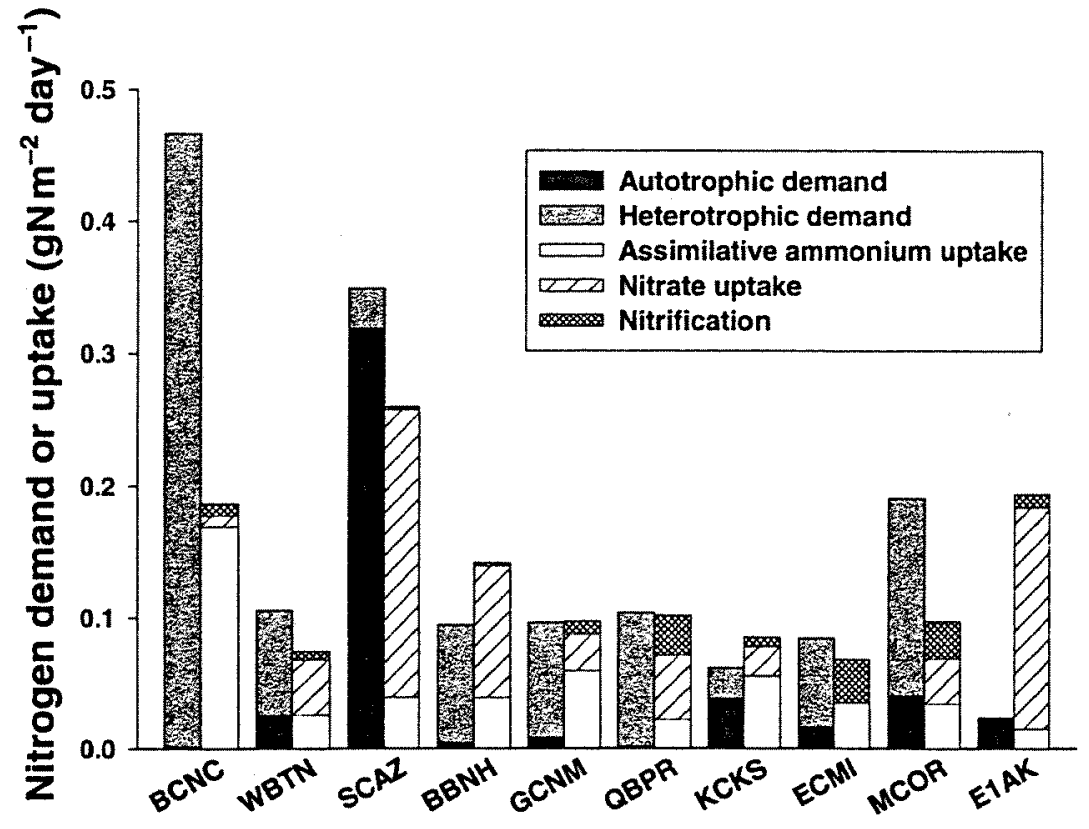

Fig. 9 Calculated metabolic nitrogen demand (left of paired bars) and measured nitrogen uptake (right of paired bars) for the LINX sites. Total demand should be compared with the sum of assimilative ammonium uptake and nitrate uptake (i.e. excluding nitrification). Site acronyms are given in Table 1.

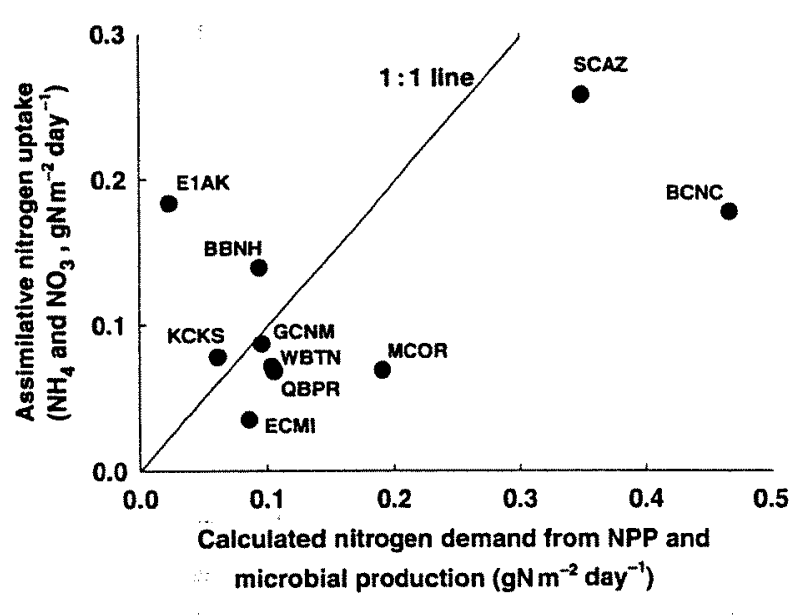

Fig. 10 Relationship between measured assimilative nitrogen uptake (i.e. not including nitrification) and calculated nitrogen demand for biomass production. The line indicates where equal values would fall. Site acronyms are given in Table 1.

(P.J. Mulholland, unpublished data) and calculated from measurements of respiration on leaves and small wood (Tank, Webster \& Benfield, 1993), a more realistic heterotrophic demand would be less than half that shown in Fig. 9. Despite this uncertainty, the dominance of calculated heterotrophic nitrogen demand agrees with measurements of actual ${ }^{15} \mathrm{~N}$ uptake in Ball Creek, where most uptake occurred on decomposing leaves and FBOM (Tank et al., 2000). Most nitrogen uptake in Ball Creek was assimilative ammonium uptake; estimated nitrate uptake and nitrification were relatively small.

We calculated no heterotrophic nitrogen demand in E1 Outlet because estimated autotrophic respiration (30\% of GPP) and nitrification exceeded measured respiration. However, E1 Outlet was the only site where we used chambers rather than changes in whole stream oxygen to measure metabolism. The chamber method probably provides a reasonable estimate of gross primary production but, as noted previously, is likely to have significantly underestimated overall ecosystem respiration in the stream. While the chamber method provides a good estimate of epilithic metabolism, it does not include important components of whole-stream metabolism (e.g. hyporheic metabolism, metabolism in particulate organic accumulations), which are likely to be predominantly heterotrophic processes. Thus, the comparable values for E1 Outlet probably lie further to the right in Figs $5 \mathrm{~b}$ and $8 \mathrm{~b}$ (ecosystem respiration) and further to the left in Figs $5 c$ and $8 c(P: R)$. Because of the limited riparian vegetation along this tundra stream, however, primary production probably does dominate nitrogen uptake, as shown by Wollheim et al. (1999) for the nearby Kuparak River. Further, the dominance of nitrate over ammonium uptake agrees with the findings of Wollheim et al. (1999).

Among the other eight streams, heterotrophic processes dominated nitrogen uptake except in the high- 
light streams, Sycamore Creek and Kings Creek. Sycamore Creek is clearly an autotrophic-based stream where the majority of nitrogen uptake results from algal assimilation of nitrate (Martí et al., 1997). Autotrophic nitrogen demand in Kings Creek was considerably lower than in Sycamore Creek, but we estimated a slight dominance of autotrophic over heterotrophic demand. Benthic sampling of various stream standing stocks for tracer ${ }^{15} \mathrm{~N}$ demonstrated that nitrogen uptake by FPOM was about twice that of periphyton in Kings Creek (Dodds et al., 2000).

Significant autotrophic nitrogen demand also occurred in Walker Branch, Eagle Creek and Mack Creek. In Walker Branch, autotrophic uptake was important early in the study, though it decreased over the course of the study with the emergence of terrestrial foliage in spring (Mulholland et al., 2000). Nevertheless, the majority of nitrogen uptake occurred on FBOM and decomposing leaves and wood at Walker Branch. For Eagle Creek, our estimates of nitrogen demand were very similar to measured nitrogen uptake. Hamilton et al. (2001) found that algal production was generally limited by light rather than nutrients and that epilithic algae accounted for about one third of assimilative nitrogen uptake and detrital microbes accounted for the remainder. In addition, almost $50 \%$ of the ammonium uptake at this site could be attributed to nitrification, probably a result of relatively high ammonium concentrations. Despite its relatively low biomass, Hamilton et al. (2001) found that epilithic algae were very highly labelled with ${ }^{15} \mathrm{~N}$, reflecting the high fraction of growing biomass compared with detrital compartments. High epilithic ${ }^{15} \mathrm{~N}$ labelling was also observed in several other streams.

As in Ball Creek, heterotrophic demand in Bear Brook, Gallina Creek and Quebrada Bisley clearly dominated nitrogen uptake. These are all small, montane streams with low nutrient concentrations and forest riparian canopies. Low autotrophic production in Gallina Creek also probably resulted from low temperature and low algal biomass as a result of flashy hydrology. In contrast to these streams, Mack Creek had relatively high autotrophic demand. Because of the relatively wide channel, the forest canopy over Mack Creek is not complete, and algal production was fairly high. Because of light limitation, primary production was very low in Quebrada Bisley (Mulholland et al., 2001; Merriam et al., 2002).
Heterotrophic uptake in this stream was not exceptionally high, as might be expected for a stream with a heavy forest canopy (such as Ball Creek), because rapid decomposition in this tropical stream results in a low standing crop of CBOM (Merriam et al., 2002). Because of this low demand, nitrification in Quebrada Bisley accounted for a considerable fraction of ammonium uptake.

The relationship between calculated nitrogen demand and measured assimilative nitrogen uptake was not statistically significant (Fig. 10; Pearson correlation, $r=0.56, P=0.09$ ). Based on the previous discussion, however, if Ball Creek nitrogen demand is reduced by half and E1 Outlet demand is increased threefold, the relationship becomes significant ( $r=0.68, P=0.03$ ), though it is still not significant with rank correlation $(r=0.19, P=0.58)$. Also, without the data for Ball Creek and E1 Outlet, the correlation is significant $(r=0.82, P=0.01)$, though the statistical significance is largely because of the high values for Sycamore Creek, and it is still not significant with rank correlation $(r=0.17, P=0.66)$. Perhaps the more useful information in Fig. 10 is the relatively small range of nitrogen uptake among the LINX streams. All of the measured rates of assimilative nitrogen uptake lie within one order of magnitude. The relative constancy of nitrogen uptake reflects metabolic compensation among streams in a variety of distinctly different biomes; that is, GPP is usually high in unshaded streams with small allochthonous inputs but low where streams are heavily shaded and the riparian trees supply large allochthonous inputs. Both autotrophic and heterotrophic metabolism require nitrogen, and clearly these biotic processes dominate DIN uptake in streams. Factors that affect the relative balance of autotrophic and heterotrophic metabolism are thus those that also control nitrogen uptake.

With the exception of the Little Miami River and Eagle Creek, our studies were conducted in small streams draining catchments with little evidence of recent disturbance. As we study a greater variety of streams, including those draining agricultural and urban catchments, will we find broader support for metabolic compensation in streams? Will this metabolic compensation be reflected in a fairly consistent nitrogen uptake or will metabolism vary more widely and nitrogen uptake become decoupled from metabolism as human impacts increasingly influence 
metabolism and nutrient inputs? These are questions we are pursuing in current research.

\section{Acknowledgments}

We appreciate the help of over 100 scientists, graduate students, undergraduate students, technicians and volunteers who helped with the collection of data used in this study. We also appreciate the help of several anonymous reviewers whose comments improved the manuscript, especially a reviewer who suggested looking at the ratio of $S_{H} / S_{W}$. The LINX study was funded by a grant (DEB-9628860) from the National Science Foundation. Work in Alaska was also funded by the National Science Foundation (OPP-9615949), and the East Fork Little Miami River study was supported by Procter \& Gamble. Work at several streams was made possible by collaboration with the U.S. Forest Service and NSF funded LTER studies. Work at Walker Branch, Tennessee, was also partially supported by the Walker Branch Watershed project, Environmental Sciences Division, Office of Biological and Environmental Research, U.S. Department of Energy under contract DE-AC05-00OR22725 with UT-Battelle, LLC.

\section{References}

Aber J.D., Nadelhoffer K.J., Steudler P. \& Melillo J.M. (1989) Nitrogen saturation in northern forest ecosystems. BioScience, 39, 378-386.

Alexander R.B., Smith R.A. \& Schwarz G.E. (2000) Effect of stream channel size on the delivery of nitrogen to the Gulf of Mexico. Nature, 403, 758-761.

American Public Health Association (APHA). (1992) Standard Methods for the Examination of Water and Wastewater. American Public Health Association, Washington, D.C.

Baker M.A., Valett H.M. \& Dahm C.N. (2000) Organic carbon supply and metabolism in a shallow groundwater ecosystem. Ecology, 81, 3133-3148.

Bencala K.E. (1983) Simulation of solute transport in a mountain pool-and-riffle stream with a kinetic mass transfer model for sorption. Water Resources Research, 19, 732-738.

Bencala K.E. (1993) A perspective on stream-catchment connections. Journal of the North American Benthological Society, 12, 44-47.

Bencala K.E. \& Walters R.A. (1983) Simulation of solute transport in a mountain pool-and-riffle stream: a transient storage model. Water Resources Research, 19, 718-724.

Bormann F.H., Likens G.E., Fisher D.W. \& Pierce R.S. (1968) Nutrient loss accelerated by clear-cutting of a forest ecosystem. Science, 159, 882-884.

Bott T.L. (1996) Primary productivity and community respiration. In: Methods of Stream Ecology (Eds F.R. Hauer \& G.A. Lamberti), pp. 533-556. Academic Press, San Diego.

Bott T.L., Brock J.T., Cushing C.E., Gregory S.V., King D. \& Petersen R.C. (1978) A comparison of methods for measuring primary productivity and community respiration in streams. Hydrobiologia, 60, 3-12.

Bott T.L., Brock J.T., Battrup A., Chambers P., Dodds W.K., Himbeault K., Lawrence J.R., Planas D., Snyder E. \& Wolfaardt G.M. (1997) An evaluation of techniques for measuring periphyton metabolism in chambers. Canadian Journal of Fisheries and Aquatic Sciences, 54, 715-725.

Bowden W.B., Peterson B.J., Finlay J. \& Tucker J. (1992) Epilithic oxygen production and consumption in a fertilised arctic stream. Hydrobiologia, 240, 121-131.

Butturini A. \& Sabater F. (1999) Importance of transient storage zones for ammonium and phosphate retention in a sandy-bottom Mediterranean stream. Freshwater Biology, 41, 593-603.

Chow V.T. (1959) Open channel hydraulics. McGraw Hill, New York.

Cole J.J. \& Pace M.L. (1995) Bacterial secondary production in oxic and anoxic freshwaters. Limnology and Oceanography, 40, 1019-1027.

Conners M.E. \& Naiman R.J. (1984) Particulate allochthonous inputs: relationships with stream size in an undisturbed watershed. Canadian Journal of Fisheries and Aquatic Sciences, 41, 1473-1484.

Crenshaw C.L., Valett H.M. \& Tank J.L. (2002) Effects of course particulate organic matter on fungal biomass and invertebrate density in the subsurface of a headwater stream. Journal of the North American Benthological Society, 21, 28-42.

Cushing C.E. \& Wolf E.G. (1984) Primary production in Rattlesnake Springs, a cold desert spring-stream. Hydrobiologia, 114, 229-236.

D'Angelo D.J., Webster J.R., Gregory S.V. \& Meyer J.L. (1993) Transient storage in Appalachian and Cascade mountain streams as related to hydraulic characteristics. Journal of the North American Benthological Society, 12, 223-235.

Dodds W.K. \& Brock J. (1998) A portable flow chamber for in situ determination of benthic metabolism. Freshwater Biology, 39, 49-59. 
Dodds W.K. \& Priscu J.C. (1990) A comparison of methods for assessment of nutrient deficiency of phytoplankton in a large oligotrohic lake. Canadian Journal of Fisheries and Aquatic Sciences, 47, 2328-2338.

Dodds W.K., Evans-White M.A., Gerlanc N.M. et al. (2000) Quantification of the nitrogen cycle in a prairie stream. Ecosystems, 3, 574-589.

Dodds W.K., Lopez A.J., Bowden W.B. et al. (2002) N uptake as a function of concentration in streams. Journal of the North American Benthological Society, 21, 206-220.

Duff J.H. \& Triska F.J. (2000) Nitrogen biogeochemistry and surface-subsurface exchange in streams. In: Streams and Ground Waters (Eds J.B. Jones \& P.J. Mulholland), pp. 197-220. Academic Press, San Diego.

Elwood J.W., Newbold J.D., O'Neill R.V. \& VanWinkle W. (1983) Resource spiralling: an operational paradigm for analyzing lotic ecosystems. In: Dynamics of Lotic Ecosystems (Eds T.D. Fontaine \& S.M. Bartell), pp. 3-27. Ann Arbor Science, Ann Arbor, Michigan.

Fellows C.S., Valett H.M. \& Dahm C.N. (2001) Wholestream metabolism in two montane streams: contribution of the hyporheic zone. Limnology and Oceanography, 46, 523-531.

Fenchel T., King G.M. \& Blackburn T.H. (1998) Bacterial Biogeochemistry: The Ecophysiology of Mineral Cycling. Academic Press, San Diego.

Fisher S.G. \& Likens G.E. (1973) Energy flow in Bear Brook, New Hampshire: an integrative approach to stream ecosystem metabolism. Ecological Monographs, 43, 421-439.

Graham J.M., Kranzfelder J.A. \& Auer M.T. (1985) Light and temperature as factors regulating seasonal growth and distribution of Ulothrix zonata (Ulvophyceae). Journal of Phycology, 21, 228-234.

Gregory S.V., Swanson F.J., McKee W.A. \& Cummins K.W. (1991) An ecosystem perspective of riparian zones: focus on links between land and water. BioScience, 41, 540-551.

Grimm N.B. (1985) Roles of Primary Producers and Consumers in Nitrogen Dynamics of a Desert Stream Ecosystem. PhD thesis, Arizona State University, Tempe, Arizona.

Grimm N.B. (1987) Nitrogen dynamics during succession in a desert stream. Ecology, 68, 1157-1170.

Grimm N.B. \& Fisher S.G. (1984) Exchange between interstitial and surface water: implications for stream metabolism and nutrient cycling. Hydrobiologia, 111, 219-228.

Hall R.O., Peterson B.J. \& Meyer J.L. (1998) Testing a nitrogen-cycling model of a forest stream by using a nitrogen-15 tracer addition. Ecosystems, 1, 283-298.

Hall R.O., Bernhardt E.S. \& Likens G.E. (2002) Relating nutrient uptake with transient storage in forested mountain streams. Limnology and Oceanography, 47, 255-265.

Hamilton S.K., Tank J.L., Raikow D.F., Wollheim W.M., Peterson B.J. \& Webster J.R. (2001) Nitrogen uptake and transformation in a midwestern US stream: a stable isotope enrichment study. Biogeochemistry, 54, 297-340.

Hart D.R. (1995) Parameter estimation and stochastic interpretation of the transient storage model for solute transport in streams. Water Resources Research, 31, 323328.

Hart B.T., Freeman P. \& McKelvie 1.D. (1992) Wholestream phosphorus release studies: variation in uptake length with initial phosphorus concentration. Hydrobiologia, 235/236, 573-584.

Hart D.R., Mulholland P.J., Marzolf E.R., DeAngelis D.L. \& Hendricks S.P. (1999) Relationships between hydrologic parameters in a small stream under varying flow and seasonal conditions. Hydrological Processes, 13, 14971510.

Harvey J.W. \& Bencala K.E. (1993) The effect of streambed topography on surface-subsurface water exchange in mountain catchments. Water Resources Research, 29, 8998.

Harvey J.W. \& Wagner B.J. (2000) Quantifying hydrologic interactions between streams and their subsurface hyporheic zones. In: Streams and Ground Waters (Eds J.B. Jones \& P.J. Mulholland), pp. 3-44. Academic Press, San Diego.

Hill W.R., Mulholland P.J. \& Marzolf E.R. (2001) Stream ecosystem responses to forest leaf emergence in spring. Ecology, 82, 2306-2319.

Holmes R.M., Fisher S.G. \& Grimm N.B. (1994) Parafluvial nitrogen dynamics in a desert stream ecosystem. Journal of the North American Benthological Society, 13, 468-478.

Holmes R.M., Jones J.B., Fisher S.G. \& Grimm N.B. (1996) Denitrification in a nitrogen-limited ecosystem. Biogeochemistry, 33, 125-146.

Holmes R.M., McClelland J.W., Sigman D.M., Fry B. \& Peterson B.J. (1998) Measuring ${ }^{15} \mathrm{~N}_{-} \mathrm{NH}_{4}{ }^{+}$in marine, estuarine, and freshwaters: an adaption of the ammonium diffusion method for samples with low ammonium concentrations. Marine Chemistry, 60, 235-243.

Hynes H.B.N. (1975) The stream and its valley. Verhandlungen der Internationale Vereinigung für Theoretische und Angewandte Limnologie, 19, 1-15.

Jones J.B. \& Holmes R.M. (1996) Surface-subsurface interactions in stream eccosystems. Trends in Ecology and Evolution, 11, 239-242.

Jones J.B., Fisher S.G. \& Grimm N.B. (1995) Nitrification in the hyporheic zone of a desert stream ecosystem. 
Journal of the North American Benthological Society, 14, 249-258.

Kemp M.J. \& Dodds W.K. (2002) Comparisons of nitrification and denitrification in prairie and agriculturally influenced streams. Ecological Applications, 12, 998-1009.

Lamberti G.A. \& Steinman A.D. (1997) A comparison of primary production in stream ecosystems. In: Stream Organic Matter Budgets (Eds J.R. Webster \& J.L. Meyer), pp. 95-104. Journal of the North American Benthological Society, 16, 3-161.

Lancaster J. \& Hildrew A.G. (1993) Characterizing in-stream flow refugia. Canadian Journal of Fisheries and Aquatic Sciences, 50, 1663-1675.

Martin L.A., Mulholland P.J., Webster J.R. \& Valett H.M. (2001) Denitrification potential in sediments of headwater streams in the southern Appalachian Mountains, USA. Journal of the North American Benthological Society, 20, 505-519.

Martí E., Grimm N.B. \& Fisher S.G. (1997) Pre- and postflood retention efficiency of nitrogen in a Sonoran Desert stream. Joumal of the North American Benthological Society, 16, 805-819.

Marzolf E.R., Mulholland P.J. \& Steinman A.D. (1994) Improvements to the diurnal upstream-downstream dissolved oxygen change technique for determining whole-stream metabolism in small streams. Canadian Journal of Fisheries and Aquatic Sciences, 51, 1591-1599.

Merriam J.L., McDowell W.H., Tank J.L., Wollheim W.M., Crenshaw C.C. \& Johnson S.L. (2002) Characterizing nitrogen dynamics, retention and transport in a tropical rainforest stream using an in situ ${ }^{15} \mathrm{~N}$ addition. Freshwater Biology, 47, 143-160.

Meybeck M. (1982) Carbon, nitrogen, and phosphorus transport by world rivers. American Joumal of Science, 282, 401-450.

Minshall G.W. (1978) Autotrophy in stream ecosystems. BioScience, 28, 767-771.

Minshall G.W., Petersen R.C., Cummins K.W., Bott T.L., Sedell J.R., Cushing C.E. \& Vannote R.L. (1983) Interbiome comparison of stream ecosystem dynamics. Ecological Monographs, 53, 1-25.

Morrice J.A., Valett H.M., Dahm C.N. \& Campana M.E. (1997) Alluvial characteristics, groundwater-surface water exchange and hydrologic retention in headwater streams. Hydrological Processes, 11, 253-267.

Mulholland P.J. \& DeAngelis D.L. (2000) Surface-subsurface exchange and nutrient spiraling. In: Streams and Ground Waters (Eds J.B. Jones \& P.J. Mulholland), pp. 149-166. Academic Press, San Diego.

Mulholland P.J., Steinman A.D. \& Elwood J.W. (1990) Measurement of phosphorus uptake length in streams: comparison of radiotracer and stable $\mathrm{PO}_{4}$ releases. Canadian Journal of Fisheries and Aquatic Sciences, 47, 2351-2357.

Mulholland P.J., Steinman A.D., Marzolf E.R., Hart D.R. \& DeAngelis D.L. (1994) Effect of periphyton biomass on hydraulic characteristics and nutrient cycling in streams. Oecologia, 98, 40-47.

Mulholland P.J., Marzoff E.R., Webster J.R., Hart D.R. \& Hendricks S.P. (1997) Evidence that hyporheic zone increase heterotrophic metabolism and phosphorus uptake in forest streams. Limnology and Oceanography, 42, 443-451.

Mulholland P.J., Tank J.L., Sanzone D.M., Wollheim W., Peterson B.J., Webster J.R. \& Meyer J.L. (2000) Nitrogen cycling in a deciduous forest stream determined from a tracer ${ }^{15} \mathrm{~N}$ addition experiment in Walker Branch, Tennessee. Ecological Monographs, 70, 471-493.

Mulholland P.J., Fellows C.S., Tank J.L. et al. (2001) Interbiome comparison of factors controlling stream metabolism. Freshwater Biology, 46, 1503-1517.

Mulholland P.J., Tank J.L., Webster J.R. et al. (2002) Can uptake length in streams be determined by nutrient addition experiments? Results from an inter-biome comparison study. Journal of the North American Benthological Society, 21, 544-560

Naegeli M.W. \& Uehlinger U. (1997) Contribution of the hyporheic zone to ecosystem metabolism in a prealpine gravel-bed river. Journal of the North American Benthological Society, 16, 794-804.

Naiman R.J. (1983) The annual pattern and spatial distribution of aquatic oxygen metabolism in boreal forest watersheds. Ecological Monographs, 53, 73-94.

Naiman R.J. \& Link G.L. (1997) Organic matter dynamics in 5 subarctic streams, Quebec, Canada. In: Stream Organic Matter Budgets (Eds J.R. Webster \& J.L. Meyer), pp. 33-39. Journal of the North American Benthological Society, 16, 3-161.

Newbold J.D., Elwood J.W., O'Neill R.V. \& VanWinkle W. (1981) Measuring nutrient spiralling in streams. Canadian Joumal of Fisheries and Aquatic Sciences, 38, 860-863.

Newbold J.D., Elwood J.W., O'Neill R.V. \& Sheldon A.L. (1983) Phosphorus dynamics in a woodland stream ecosystem: a study of nutrient spiralling. Ecology, 64, 1249-1265.

Odum H.T. (1956) Primary production in flowing waters. Limnology and Oceanography, 1, 102-117.

Packman A.I. \& Bencala K.E. (2000) Modeling surface subsurface hydrological interactions. In: Streams and Ground Water (Eds J.B. Jones \& P.J. Mulholland), pp. 45-80. Academic Press, San Diego. 
Peterson B.J., Bahr M. \& Kling G.W. (1997) A tracer investigation of nitrogen cycling in a pristine tundra river. Canadian Joumal of Fisheries and Aquatic Sciences, 54, 2361-2367.

Peterson B.J., Wollheim W., Mulholland P.J. et al. (2001) Control of nitrogen export from watersheds by headwater streams. Science, 292, 86-90.

Pusch M. \& Schwoerbel J. (1994) Community respiration in hyporheic sediments of a mountain stream (Steina, Black Forest). Archiv für Hydrobiologie, 130, 35-52.

Ross H.H. (1963) Stream communities and terrestrial biomes. Archiv für Hydrobiologie, 59, 235-242.

Seitzinger S.P. (1988) Denitrification in freshwater and coastal marine ecosystems: Ecological and geochemical significance. Limnology and Oceanography, 33, 702-724.

Seitzinger S.P. \& Sanders R.W. (1997) Contribution of dissolved organic nitrogen from rivers to estuarine eutrophication. Marine Ecology Progress Series, 159, 1-12.

Steinhart G.S., Likens G.E. \& Groffman P.M. (2001) Denitrification in stream sediments of five northeastern (USA) streams. Verhandlungen der Internationale Vereinigung für Theoretische und Angewandte Limnologie, 27, 1331-1336.

Stepanauskas R., Edling H. \& Tranvik L.J. (1999) Differential dissolved organic nitrogen availability and bacterial aminopeptidase activity in limnic and marine waters. Microbial Ecology, 38, 264-272.

Stream Solute Workshop. (1990) Solute dynamics in streams. Journal of the North American Benthological Society, 9, 95-119.

Tank J.L., Webster J.R. \& Benfield E.F. (1993) Microbial respiration on decaying leaves and sticks in a southern Appalachian stream. Journal of the North American Benthological Society, 12, 394-405.

Tank J.L., Meyer J.L., Sanzone D.M., Mulholland P.J., Webster J.R., Peterson B.J., Wollheim W.M. \& Leonard N.E. (2000) Analysis of nitrogen cycling in a forest stream during autumn using a ${ }^{15} \mathrm{~N}$-tracer addition. Limnology and Oceanography, 45, 1013-1029.

Triska F.J., Kennedy V.C., Avanzino R.J., Zellweger G.W. \& Bencala K.E. (1989) Retention and transport of nutrients in a third-order stream in northwestern California: hyporheic processes. Ecology, 70, 1893-1905.

United States Geological Survey (USGS). (2000) Environmental Setting and Effects on Water Quality in the Great and Little Miami River basins, Ohio and Indiana. National Water-Quality Assessment Program, Water Resources Investigation Report 99-04201, Columbus, Ohio.

Uzarski D.G. (1999) Community Metabolism in Michigan Rivers: Effects of Including Hyporheic Sediments in Estimates of Production/Respiration (P/R) Ratios. PhD thesis, Michigan State University, East Lansing, Michigan.

Valett H.M., Fisher S.G., Grimm N.B. \& Camill P. (1994) Vertical hydrologic exchange and ecological stability of a desert stream ecosystem. Ecology, 75, 548-560.

Valett H.M., Morrice J.A., Dahm C.N. \& Campana M.E. (1996) Parent lithology, surface-groundwater exchange, and nitrate retention in headwater streams. Limnology and Oceanography, 41, 333-345.

Valett H.M., Dahm C.N., Campana M.E., Morrice J.A., Baker M.A. \& Fellows C.S. (1997) Hydrologic influences on groundwater-surface water ecotones: heterogeneity in nutrient composition and retention. Journal of the North American Benthological Society, 16, 239-247.

Vannote R.L., Minshall G.W., Cummins K.W., Sedell J.R. \& Cushing C.E. (1980) The river continuum concept. Canadian Journal of Fisheries and Aquatic Sciences, 37, 130-137.

Vitousek P.M., Aber J.D., Howarth R.W., Likens G.E., Matson P.A., Schindler D.W., Schlesinger W.H. \& Tilman D.G. (1997) Human alteration of the global nitrogen cycle: sources and consequences. Ecological Applications, 7, 737-750.

Wagner B.J. \& Harvey J.W. (1997) Experimental design for estimating parameters of rate-limited mass transfer: analysis of stream tracer studies. Water Resources Research, 33, 1731-1741.

Webster J.R. \& Ehrman T.P. (1996) Solute dynamics. In: Methods in Stream Ecology (Eds F.R. Hauer \& G.A. Lamberti), pp. 145-160. Academic Press, San Diego.

Webster J.R. \& Patten B.C. (1979) Effects of watershed perturbation on stream potassium and calcium dynamics. Ecological Monographs, 49, 51-72.

Webster J.R., Gurtz M.E., Hains J.J., Meyer J.L., Swank W.T., Waide J.B. \& Wallace J.B. (1983) Stability of stream ecosystems. In: Stream Ecology (Eds J.R. Barnes \& G.W. Minshall), pp. 355-395. Plenum Press, New York.

Webster J.R., Tank J.L., Wallace J.B., Meyer J.L., Eggert S.L., Ehrman T.P., Ward B.R., Bennett B.L., Wagner P.F. \& MCTammany M.E. (2000) Effects of litter exclusion and wood removal on phosphorus and nitrogen retention in a forest stream. Verhandlungen der Internationale Vereinigung für Theoretische und Angewandte Limnologie, 27, 1337-1340.

Wetzel R.G. \& Likens G.E. (2000) Limnologcal Analyses. Springer-Verlag, New York.

Wollheim W.M., Peterson B.J., Deegan L.A., Bahr M., Hobbie J.E., Jones D., Bowden W.B., Hershey A.E., Kling G.W. \& Miller M.C. (1999) A coupled field and modeling approach for the analysis of nitrogen cycling 
1352 J.R. Webster et al.

in streams. Journal of the North American Benthological Society, 18, 199-221.

Wollheim W.M., Peterson B.J., Deegan L.A., Hobbie J.E., Hooker B., Bowden W.B., Edwardson K.J., Arscott D.B., Hershey A.E. \& Finlay J. (2001) Influence of stream size on ammonium and suspended particulate nitrogen processing. Limnology and Oceanography, 46, 1-13.
Young R.G. \& Huryn A.D. (1998) Comment: Improvements to the diurnal upstream-downstream dissolved oxygen change technique for determining wholestream metabolism in small streams. Canadian Journal of Fisheries and Aquatic Sciences, 55, 1784-1785.

(Manuscript accepted 3 April 2003) 